\title{
Review \\ Biosensors Based on Bivalent and Multivalent Recognition by Nucleic Acid Scaffolds
}

\author{
Hokyung Kim ${ }^{\dagger}$, Hayeon Choi ${ }^{\dagger}$, Yoonji Heo ${ }^{\dagger}$, Cheoljae Kim *(D), Min Kim * (D) and Ki Tae Kim *(i) \\ Department of Chemistry, Chungbuk National University, Cheongju 28644, Korea; hkkim@chungbuk.ac.kr (H.K.); \\ hayeoni@chungbuk.ac.kr (H.C.); gjdbsw198@gmail.com (Y.H.) \\ * Correspondence: iamckim@chungbuk.ac.kr (C.K.); minkim@chungbuk.ac.kr (M.K.); ktkim@chungbuk.ac.kr (K.T.K.); \\ Tel.: +82-43-261-2305 (C.K.); +82-43-261-2283 (M.K.); +82-43-261-2286 (K.T.K.) \\ † These authors contributed equally to this work.
}

check for updates

Citation: Kim, H.; Choi, H.; Heo, Y.; Kim, C.; Kim, M.; Kim, K.T. Biosensors Based on Bivalent and Multivalent Recognition by Nucleic Acid Scaffolds. Appl. Sci. 2022, 12, 1717. https://doi.org/10.3390/ app12031717

Academic Editor: Nunzio Cennamo

Received: 7 January 2022

Accepted: 5 February 2022

Published: 7 February 2022

Publisher's Note: MDPI stays neutral with regard to jurisdictional claims in published maps and institutional affiliations.

Copyright: (c) 2022 by the authors. Licensee MDPI, Basel, Switzerland. This article is an open access article distributed under the terms and conditions of the Creative Commons Attribution (CC BY) license (https:/ / creativecommons.org/licenses/by/ $4.0 /)$.

\begin{abstract}
Several biological macromolecules adopt bivalent or multivalent interactions to perform various cellular processes. In this regard, the development of molecular constructs presenting multiple ligands in a specific manner is becoming crucial for the understanding of multivalent interactions and for the detection of target macromolecules. Nucleic acids are attractive molecules to achieve this goal because they are capable of forming various, structurally well-defined 2D or 3D nanostructures and can bear multiple ligands on their structures with precisely controlled ligand-ligand distances. Thanks to the features of nucleic acids, researchers have proposed a wide range of bivalent and multivalent binding agents that strongly bind to target biomolecules; consequently, these findings have uncovered new biosensing strategies for biomolecule detection. To date, various bivalent and multivalent interactions of nucleic acid architectures have been applied to the design of biosensors with enhanced sensitivity and target accuracy. In this review, we describe not only basic biosensor designs but also recently designed biosensors operating through the bivalent and multivalent recognition of nucleic acid scaffolds. Based on these designs, strategies to transduce bi- or multivalent interaction signals into readable signals are discussed in detail, and the future prospects and challenges of the field of multivalence-based biosensors are explored.
\end{abstract}

Keywords: biosensor; bivalent interaction; multivalent interaction; biomolecule; nucleic acid; protein; DNA nanostructure; fluorescence

\section{Introduction}

Bivalent or multivalent interactions are the most prevalent binding modes found in various biological systems. Many biomolecular components adopt multivalent interactions to overcome weak, monovalent, non-covalent interactions and to make their biomolecular interactions stronger and more specific, ultimately enabling the occurrence of desired biological processes [1]. For example, antibodies use two antigen recognition parts for immune response, and viruses utilize multivalent interactions to attach themselves to host cells [2,3]. In addition, cells use many multivalent receptors for cell signaling [4]. These examples indicate that bivalent and multivalent interactions are an indispensable part of biological processes that should be understood and utilized for the development of biotechnologies.

Inspired by these observations, the concept of multivalent interactions has been applied to the design of artificial molecular constructs capable of multivalent binding. In such constructs, multiple ligands connected to each other are placed at specified positions to mimic the pattern of receptors in the target [1,5]. Such a design endows the construct with positive cooperativity in its binding; thus, the construct more strongly and selectively binds to the target biomolecules. Owing to their attractive features, such as enhanced binding capability, multivalent biomolecular interactions have been considered a useful strategy for the study of biology, biotechnology, and pharmaceutical drug design [6,7]. In particular, 
multivalent interactions are expected to provide new, advanced strategies for the design of biosensors targeting macromolecules with multiple binding modes.

Among diverse polymer candidates, nucleic acids have been considered promising scaffolds for the design of biosensors based on multivalent displays of ligands for several reasons (Figure 1). First, nucleic acid helices based on Watson-Crick base pairs have constant base-pair distances of $3.4 \AA$. The distance between ligands can be precisely controlled by introducing ligands into designated positions of nucleotides [8-11]; strategies involving such ligand-nucleotide conjugation are well known [12]. Second, helical structures of nucleic acids provide rigidity that enables the predictable design of ligand displays. Third, nucleic acids readily provide secondary structures of diverse shapes, such as A-helices, B-helices, hairpins, and quadruplexes [13]. Such structural diversity enables ligand arrays of numerous shapes and patterns to be prepared on 2D or 3D nanostructures $[14,15]$. Lastly, nucleic acids can readily convert biomolecular interaction signals into specific forms of output, mainly nucleic acid strands. To date, many types of DNA nanodevices, including those that perform DNA computing and DNA nanomachines, commonly initiated by inputting a nucleic acid strand, have been invented [16-18]. The integration of DNA-based multivalent recognition and nanodevices would facilitate the design of biosensors that amplify the signals of multivalent interactions. Accordingly, nucleic acid scaffolds are the most promising materials for the design of multivalent-based biosensors. Various types of biosensors have been designed and constructed on nucleic acids to reveal the bivalent or multivalent interactions of biological macromolecules.

\section{Nucleic acid scaffolds for biomolecular interactions}

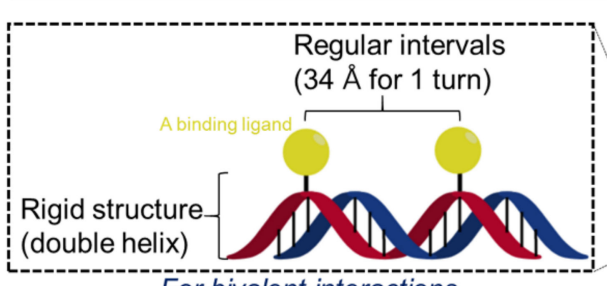

For bivalent interactions

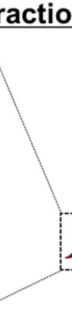

For multivalent interactions

Figure 1. Advantageous features of nucleic acids for bivalent and multivalent interactions.

This review focuses on the design strategies of biosensors rather than their biological targets. We first explore basic biosensor designs and recent examples of biosensors based on bivalent and multivalent biomolecular interactions directed by nucleic acid hybridizations and structures. Then, we discuss the design principles of nucleic acid scaffolds that can precisely recognize a target through bivalent or multivalent interactions. Various strategies for obtaining readable signals (e.g., fluorescence) from bivalent or multivalent biomolecular interactions are then discussed. Based on the features of the biosensors discussed herein, we lastly propose potential, novel biosensors targeting unexplored biological multivalent targets.

\section{Biosensors Based on Bivalent Binding Modes}

Bivalent binding is the most basic form of multivalent interactions and is frequently found in biological processes. The simplicity of bivalent systems allows researchers to design many types of biosensors. Although these systems are easy to understand, it is important to extensively consider bivalent sensor designs because they are becoming fundamental components of multivalent sensors. In this section, four types of biosensors based on the bivalent binding of nucleic acid scaffolds are described: those based on proximity-induced hybridization, DNA displacement, and steric strain-induced distance change, as well as DNA nanodevices. Two or three characteristic studies are provided alongside other references to describe the concept of each strategy. 


\subsection{Biosensors Based on Proximity-Induced Hybridization}

The concept of bivalent biosensors based on proximity-induced nucleic acid hybridization was first reported by the Landegren group in 2002 [19]. This strategy is based on the DNA ligation of two adjacent probe oligonucleotides via bivalent binding; it is called proximity ligation assay (PLA). Two oligonucleotides containing an aptamer for the cytokine platelet-derived growth factor B-chain (PDGF-B) were ligated to each other using T4 DNA ligase and connector oligonucleotides in the presence of only a homodimeric form of PDGF-B (PDGF-BB) (Figure 2). The ligated product was amplified by real-time polymerase chain reaction (qPCR) and analyzed using a $5^{\prime}$-nuclease assay, affording a fluorescence signal. This PLA using bivalent interactions allowed for the detection of a target protein, PDGF, on a zeptomole scale $\left(40 \times 10^{-21} \mathrm{~mol}\right)$. The concept of proximity ligation has been further applied to protein-specific glycosylation [20]; the quantification of certain $\mathrm{O}-\mathrm{GlcNAc}$ proteins [21]; the detection of tumor-derived exosomal PD-L1 [22], cytokines [23], and other proteins [24-31]; as well as COVID-19 diagnosis [32]. Moreover, this concept has been combined with an enzymatic amplification system to afford an ultrasensitive protein sensor [33].

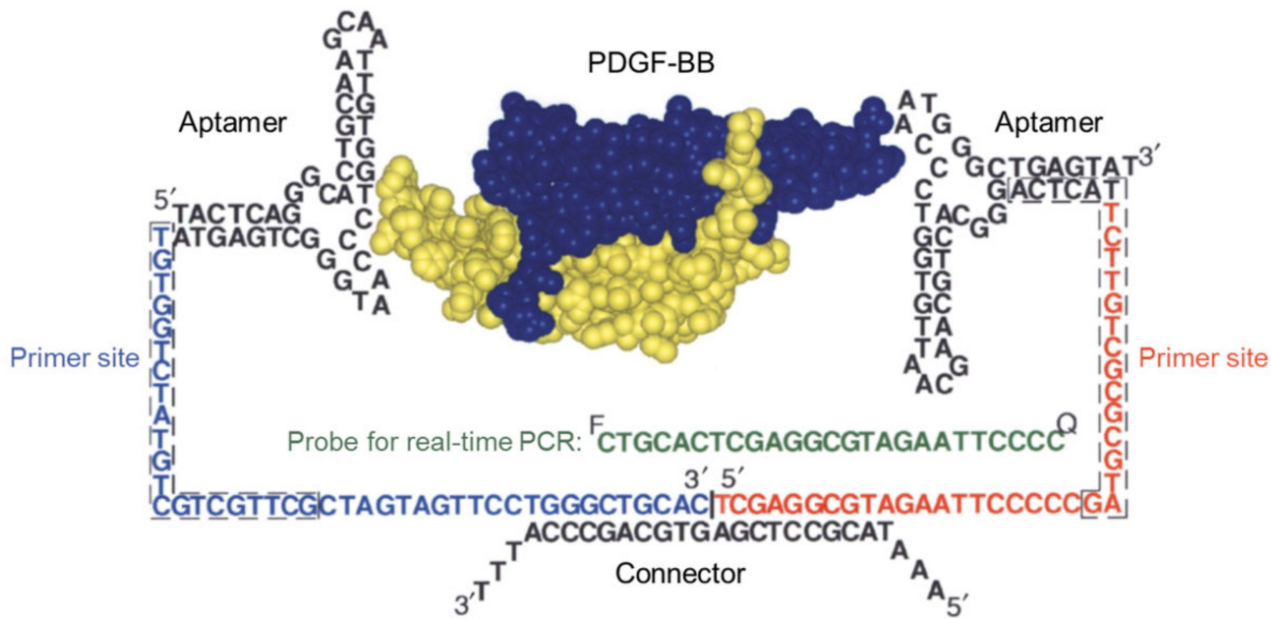

Figure 2. Structure and conceptual scheme of proximity ligation assay (PLA) for the detection of PDGF-BB. Reprinted by permission from Springer Nature Ltd.: Nat. Biotechnol. 2002, 20, 473-477, doi:10.1038/nbt0502-473. Copyright (2002) [19].

Nine years later, in 2011, a modified PLA called the proximity extension assay (PEA) was suggested by the Fredriksson group to overcome the limitations of PLA; notably, it showed moderate efficacy in human plasma [29]. PEAs utilize two antibody-conjugated oligonucleotide probes to detect specific antigens with bivalent interactions. In the presence of an antigen, the two probes cooperatively bind to the antigen and hybridize with each other using short overhangs. Unlike the PLA method, PEAs then employ DNA polymerase to extend the hybridizing oligonucleotides; this produces fully extended double-stranded DNA templates. The obtained template is then quantified by qPCR (Figure 3). The PEA method has shown high sensitivity and specificity and has thus been able to detect femtomolar levels of interleukin-8 (IL-8) and glial-derived neurotrophic factor (GDNF) proteins, even in human plasma. Recently, PEA strategies have also been utilized for measuring the levels of single-cell proteins [34], detecting extracellular vesicle (EV) proteins [35,36], C-reactive protein, cardiac troponin I [37], or plasma proteins [38], monitoring drug-target interactions, [39] or profiling proteins in plasma samples of COVID-19 patients [31,40]. 


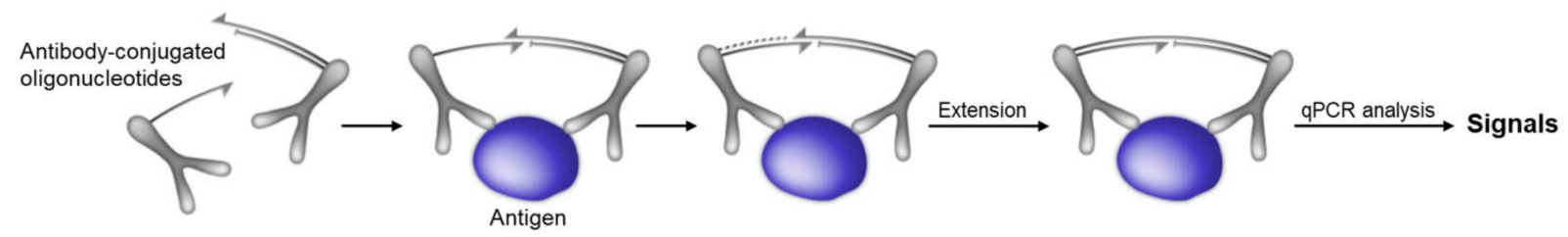

Figure 3. Conceptual scheme of proximity extension assays (PEA) for the detection of biomolecules such as antigens. Reproduced by permission of Oxford University Press: Nucleic Acids Res. 2011, 39, e102, doi:10.1093/nar/gkr424. Copyright (2011) [29].

In addition to PLAs and PEAs, relatively simpler designs have been adopted for biosensors that afford signals arising directly from proximity-induced hybridization. In this design, signaling molecules are directly linked to DNA scaffolds. A recent study reported by the Jungmann group in 2021 [41] described the development of a detection system, proximity-DNA point accumulation in nanoscale topology (pPAINT), that relies on the spatial proximity between split docking sites. Namely, two rationally designed DNA molecules comprising docking, stem, and leash parts afford the hybridization of the stem and a complete docking strand when the two targets are in close proximity. Moreover, the transient binding of the imager strand to the docking strand allowed for the collection of fluorescent signals at the docking site, and a super-resolution image of the protein-protein interaction was reconstructed (Figure 4). This method enables the visualization of $\alpha$ - and $\beta$-tubulin in close proximity with high sensitivity and low false-positive rates.
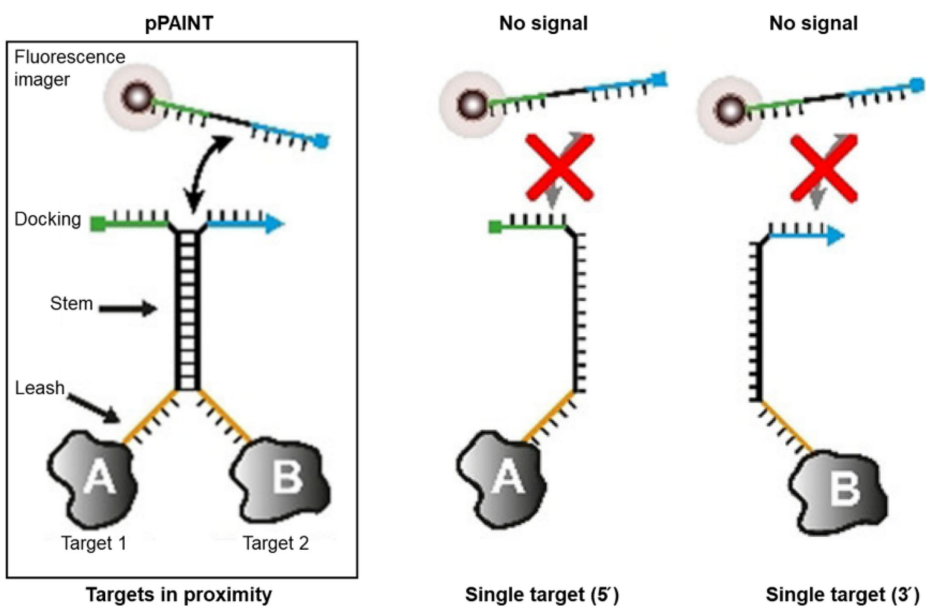

Figure 4. Biosensing strategy of proximity-DNA point accumulation in nanoscale topology (pPAINT) for direct signaling from proximity-induced hybridization induced by bivalent interactions [41].

A similar biosensor design was reported in the same year by He et al. [42]. This study is also based on the spatial proximity of DNA strands arising from the presence of a target. The system consisted of gold nanoparticles (AuNPs) bearing fluorophore-labeled DNA and a pair of DNA-antibody conjugates, each having a split fragment of a DNAzyme. In the presence of the target viruses, enteroviruses EV71 and CVB3, the antibody on each conjugate binds to the virus, and, consequently, the activity of the DNAzyme is restored. Then, the fluorophore-labeled DNA, the target of the DNAzyme, is cleaved to release the fluorophore from the AuNPs, which produces a fluorescence signal (Figure 5). This system demonstrates that simple biosensors based on proximity-induced hybridization are capable of detecting viruses in clinical samples. 


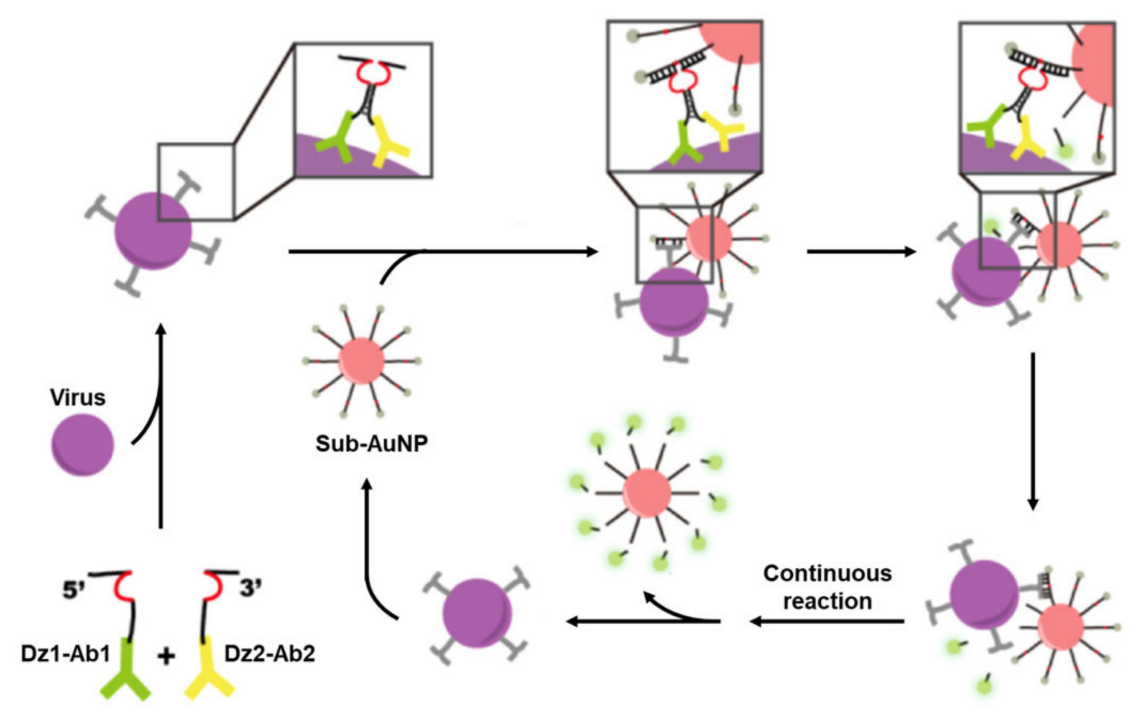

Figure 5. Principle operation of a biosensor for virus detection. The method is enabled by proximityinduced DNAzyme formation and fluorophore-labeled gold nanoparticles (AuNPs). Adapted with permission from Anal. Chem. 2021, 93, 5606-5611, doi:10.1021/acs.analchem.1c00335. Copyright (2021) American Chemical Society [42].

In 2018, Ricci et al. designed the simplest bivalent biosensor for antibodies based on proximity-induced hybridization [43]. While other proximity-induced hybridization methods require an additional strand for signaling, this method requires only a pair of split green fluorescent protein (GFP)-mimic RNA aptamers modified with an antigen as a signaling component. The presence of an antibody gives rise to the assembly of aptamers that afford a binding site for 3,5-difluoro-4-hyroxybenzylidene imidazoline (DFHBI), which yields a fluorescent signal upon binding (Figure 6). Through this method, different types of antibodies were selectively detected. Furthermore, despite its simplicity, the design showed high binding affinity, and target specificity originating from bivalent binding and worked well even in crude cellular extracts.
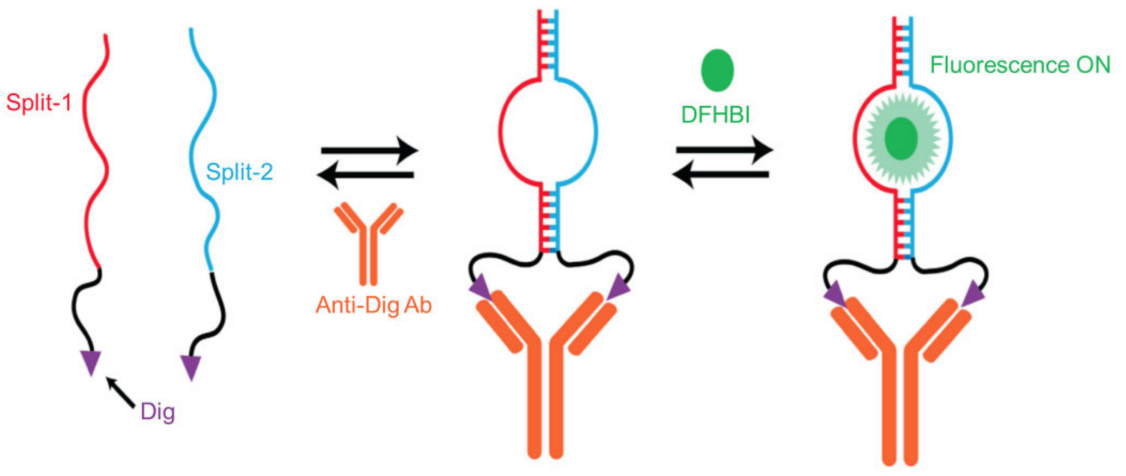

Figure 6. Conceptual scheme for a fluorogenic antibody sensor based on split green fluorescent protein (GFP)-mimic RNA aptamers and 3,5-difluoro-4-hyroxybenzylidene imidazoline (DFHBI). Adapted with permission from Anal. Chem. 2018, 90, 1049-1053, doi:10.1021/acs.analchem.7b02102. Copyright (2018) American Chemical Society [43].

Recently, other, similar approaches have also used proximity-induced hybridization to produce advanced bivalent biosensors; these include an electrochemical proximity assay for the femtomolar detection of insulin [44], a biosensor employing nicking endonucleaseassisted isothermal fluorescence signal amplification for the detection of streptavidin or prostate-specific antigen (PSA) [45], a proximity hybridization-regulated DNA biogate for PSA detection [46], a DNAzyme-based DNA nanomotor for detection of thrombin [47], a 
cytosensor for the detection of circulating tumor cells [48], a scattering proximity immunoassay based on the dimerization of AuNPs for detecting carcinoembryonic antigen [49], and other enzymatic methods [50,51]. Moreover, proximity-induced hybridization has been combined with templated reaction techniques to identify antibodies [52]. These recent studies imply that proximity-induced hybridization is a simple yet potent strategy for building biosensors based on bivalent binding.

\subsection{Biosensors Based on DNA Displacement}

Inspired by proximity-based assays, biosensors based on DNA displacement arising from bivalent interactions have emerged as detection methods for target proteins; this strategy is in line with the binding-induced DNA assembly principle called BINDA (Figure 7A) [53]. In 2012, Le et al. designed a protein assay based on the displacement of fluorescent oligonucleotides on AuNPs [54]. In this system, a probe sequence was hybridized with an oligonucleotide conjugated with the AuNPs; consequently, the fluorescence was quenched by the AuNPs in the absence of the target protein. However, in the presence of the target protein, the protein-ligand binding forces the probe to switch with a competing DNA strand by bringing them in close proximity to one another; this leads to restored fluorescence (Figure 7B). This concept was further applied to the detection of PDGF-BB, where the probe strand was successfully displaced because of the strong affinity between the aptamers and PDGF-BB, and the fluorescence signal increased. This method enabled the selective detection of nanomolecular concentrations of the target protein.

(A)

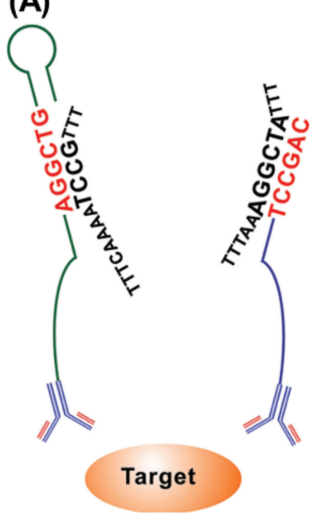

(B)

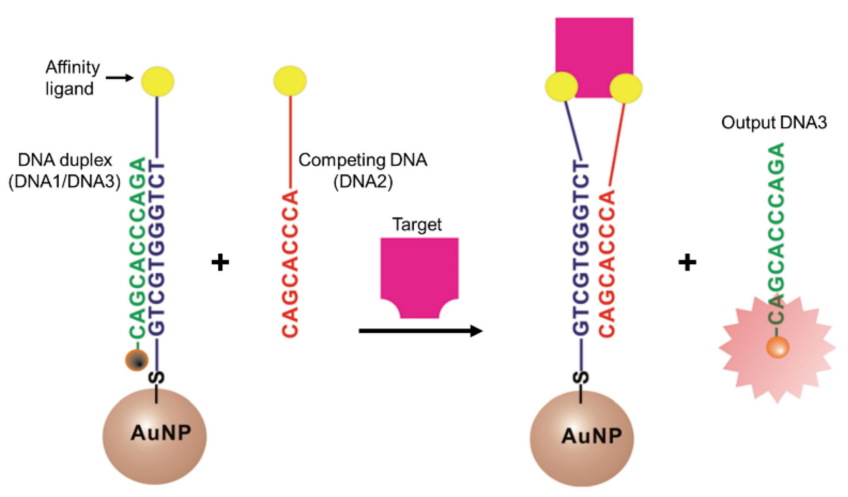

Figure 7. (A) Conceptual scheme of binding-induced DNA assembly (BINDA). Adapted with permission from Anal. Chem. 2012, 84, 877-884, doi:10.1021/ac203207g. Copyright (2012) American Chemical Society [53]. (B) Principal scheme of a biosensor based on bivalent interaction-induced DNA displacement on AuNPs. Reproduced by permission from John Wiley \& Sons Ltd.: Angew. Chem. Int. Ed. 2012, 51, 9317-9320, doi:10.1002/anie.201202677. Copyright (2012) [54].

More recently, in 2018, Tan et al. developed a strategy using a proximity-induced DNA assembly that they used for imaging protein dimerization [55]. Specifically, when two proteins are dimerized on a cell membrane, two FAM-modified aptamer probes specific to a target membrane protein are in close proximity and thus form a stable stem; this provides an initiator strand for the displacement process. The initiator triggers DNA strand displacement of signal output probes containing a Cy5 and quencher pair to form a three-way junction structure. As a result, $\mathrm{Cy} 5$ is released from the quencher, which restores the fluorescence of Cy5 (Figure 8). Using this strategy, protein dimerization, such as the dimerization of the Met receptor or the transforming growth factor- $\beta$ type II receptor, was clearly visualized on the surface of living cells in real-time. 


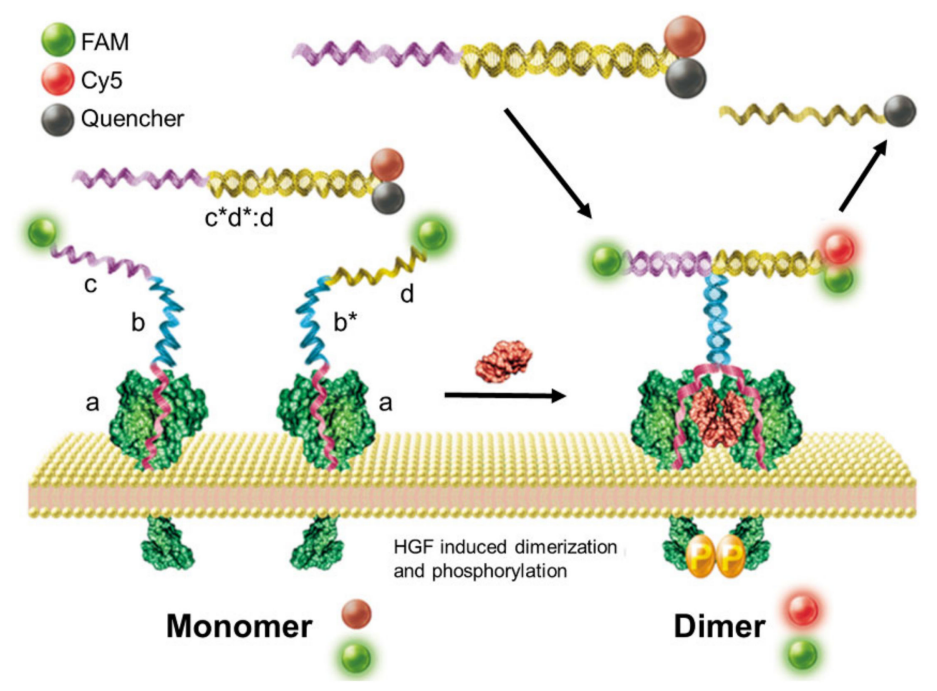

Figure 8. Design of a fluorescent biosensor based on proximity-induced displacement for monitoring protein dimerization. Adapted with permission from J. Am. Chem. Soc. 2018, 140, 4186-4190, doi:10.1021/jacs.7b11311. Copyright (2018) American Chemical Society [55].

To date, bivalent binding-induced DNA displacement has been used to sense streptavidin on magnetic beads [56,57], thrombin [58-62], PDGF [63-65], human epidermal growth factor receptor-2 (HER2) in live cells [66], human acute lymphoblastic leukemia cells (CCRF-CEM) [67], prostate-specific antigen (PSA) [68-70], antibodies [71-74], cardiac troponin [75], and other, specific cells [76]. Additionally, streptavidin has been detected using chemiluminescent detection based on a DNA walker [77], and antibodies have been identified through quantum dot doping methods [78]. Moreover, DNA displacement has been combined with other enzymatic amplification systems [79,80]; for example, rolling circle amplification (RCA) and CRISPR/Cas12a systems were recently conjugated with DNA displacement strategies to detect femtomolar levels of thrombin [81].

\subsection{Biosensors Based on DNA Nanodevices}

DNA displacement strategies were further modified to create new, improved biosensing systems, including a DNA displacement-based sensor combined with DNA nanostructures or nanodevices [82]. In 2013, Le et al. demonstrated dynamic DNA assemblies triggered by output DNA released from binding-induced DNA displacement [83]. In this design, the output DNA strand $(\mathrm{O})$ acts as an initiator strand of the two-step DNA circuit (Figure 9). As a result, the DNA circuit produces a fluorescent signal in the presence of streptavidin. The detection threshold of the combined system was lower than one nanomolar, owing to the greater than 10-fold amplification effect of the DNA circuit. This combined DNA circuit system was also utilized for the detection of thrombin [84-86] and other proteins [87], for the identification of antibodies [88], and for developing a strip biosensor capable of the amplified detection of nerve growth factor-beta (NGF- $\beta$ ) [89].

Encouraged by this result, more complex DNA nanodevices were recruited to transduce signals from bivalent biomolecular interactions to readable signals. One recent example was achieved by Tan et al. in 2019 [90], where the authors proposed a combined system comprising a DNA scaffold and a hybridization chain reaction (HCR) for bivalent recognition and reporting, respectively, to provide single-step cancer cell identification (Figure 10). HCR is a process where two metastable nucleic acid hairpins are iteratively hybridized to each other to form a long stretch of a double helix [91]. Cell-type identification was achieved using aptamers that recognize biomarkers specific to individual types of cancer cells. In the presence of the target biomarkers on the cell, with the aid of a connector strand, two aptamer sequences form a DNA bridge-bearing associated toehold. The generated toehold then becomes an initiator of the HCR, and the fluorescent oligonu- 
cleotide is elongated to visualize the cells. Using such an AND logic gate strategy based on bivalent interactions, a specific cancer cell was identified among several cancer cell lines. Furthermore, a triple-aptamer-based system using trivalent interactions has been suggested for more elaborate cell identification. These results demonstrate that such devices can visualize target proteins with excellent selectivity and sensitivity. Inspired by this work, an HCR system initiated by bivalent interactions was recently applied to the sensitive electrochemical sensing of thrombin [92] and was used in viral sensors based on cascade amplification using DNAzyme assemblies [93] or in the detection of antibodies [94].

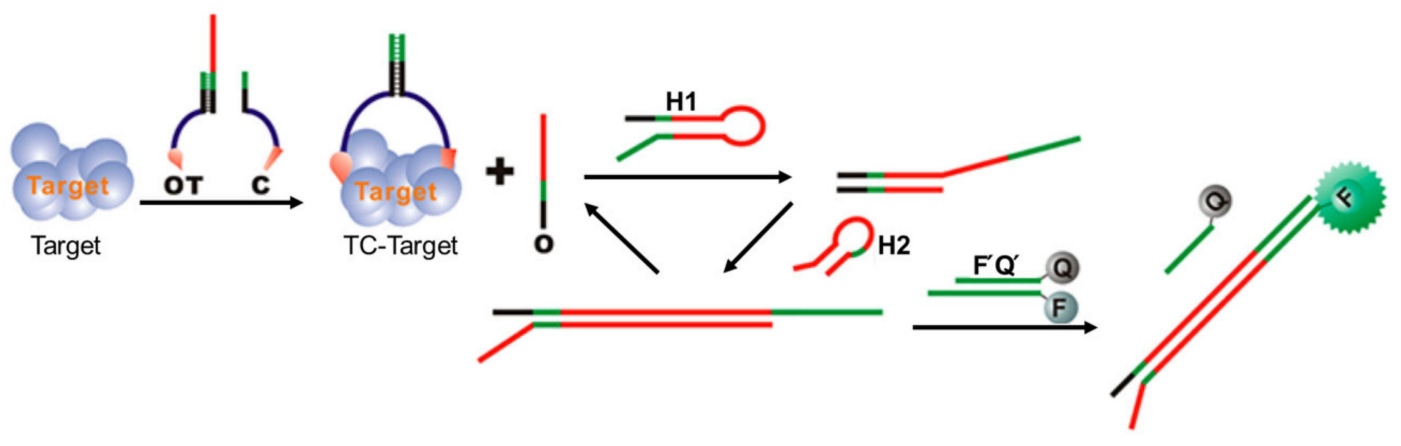

Figure 9. Scheme of a protein sensor based on DNA displacement and a catalytic DNA circuit for signal amplification. Adapted with permission from J. Am. Chem. Soc. 2013, 135, 2443-2446, doi:10.1021/ja311990w. https:/ / pubs.acs.org/doi/full/10.1021/ja311990w (accessed on 31 January 2021). Copyright (2013) American Chemical Society [83].
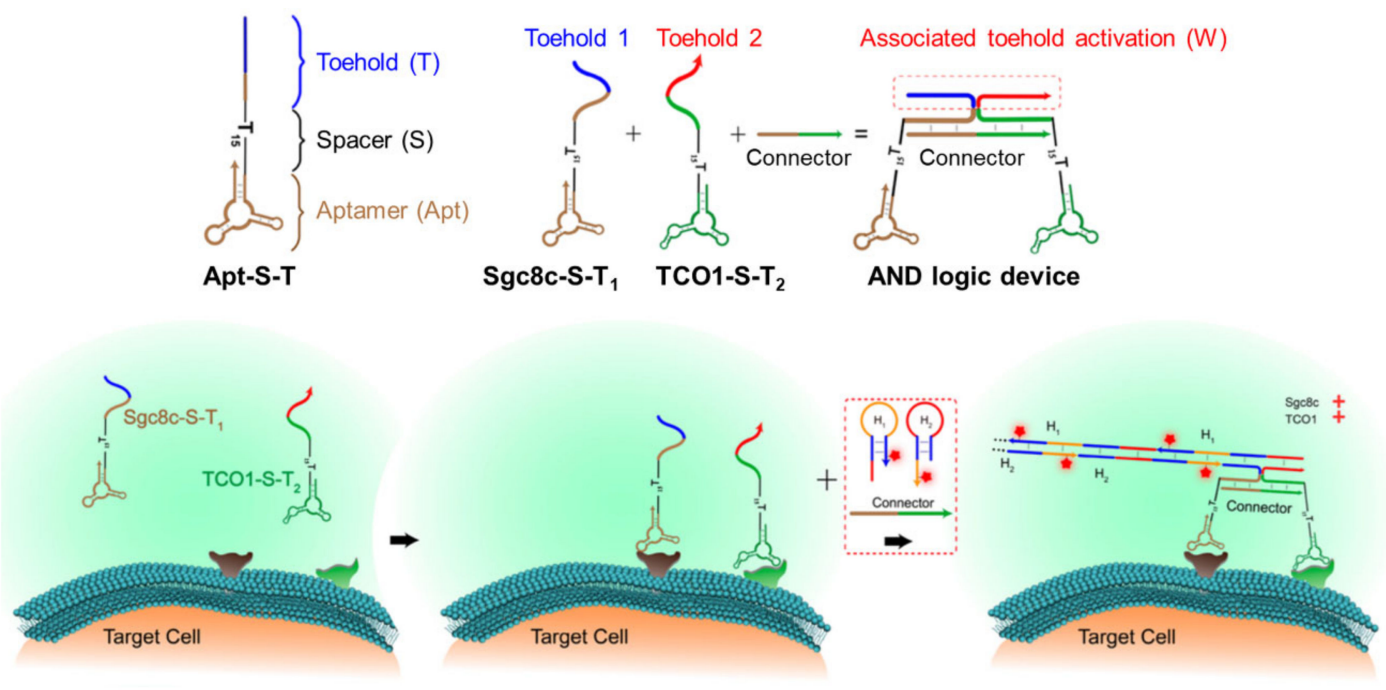

Figure 10. Scheme of a cancer cell identification system based on bivalent interactions between cells and aptamers. Fluorescence signaling is enabled by a hybridization chain reaction (HCR). Adapted with permission from J. Am. Chem. Soc. 2019, 141, 12738-12743, doi:10.1021/jacs.9b05470. Copyright (2019) American Chemical Society [90].

\subsection{Biosensors Based on Steric Strain-Induced Distance Change}

In contrast to strategies based on nucleic acid displacement, a biosensor's response to changing distances between binding sites has been studied by a few groups. Among them, in 2015, the Ricci group reported a DNA-based beacon for antibody detection [95]. The beacon consists of a DNA hairpin bearing a fluorophore and quencher pair and two additional single-stranded tails that serve as antigen-carrying oligonucleotides. In a relaxed state, the beacon forms a hairpin structure, and the resulting close proximity between the fluorophore and quencher quenches the fluorescence. However, in the presence of target antibodies, steric strain induced by the bivalent binding of the antibody to the 
beacon opens the hairpin, rapidly restoring the fluorescence (Figure 11, top). Through this distance-dependent strategy, antibodies or proteins at low nanomolar concentrations were detected rapidly and selectively, even in complex samples. Furthermore, this method was also applicable to the sensing of a monovalent protein or the simultaneous sensing of two different antibodies through AND logic gate operation (Figure 11, bottom). More recently, the same strategy was adopted for the detection of a single antibody in a DNA origami nanoantenna [96].
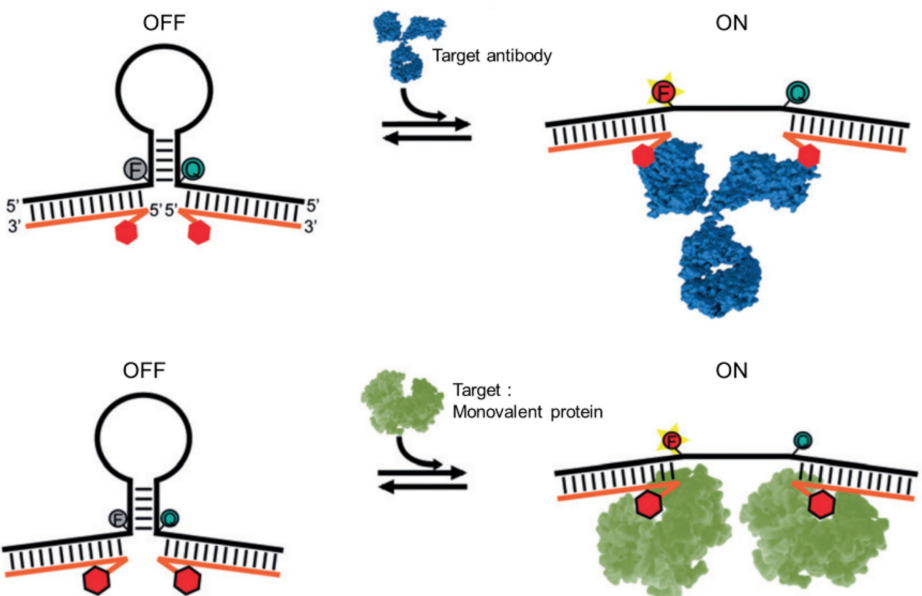

Figure 11. The structure and principle of a DNA-based beacon for the detection of antibodies. The antibody exerts steric strain on the beacon and changes the distance between a fluorophore and quencher. Reproduced by permission from John Wiley \& Sons Ltd.: Angew. Chem. Int. Ed. 2015, 127, 13412-13416, doi:10.1002/ange.201505179. Copyright (2015) [95].

DNA structural changes due to bivalent interactions have also been applied to other concepts. In 2017, the same group reported DNA-based nanomachines that can release nucleic acid cargo strands upon bivalent binding to a target antibody [97]. The DNA nanomachine has a DNA triplex structure, where a clamp-like structure holds a cargo strand inside through both Watson-Crick and Hoogsteen base pairs. Because each side of the clamp-like structure is conjugated with a specific antigen, the nanomachine can bind to the antibody through bivalent interactions. In the triplex structure, the cargo strand, bearing a fluorophore and quencher at each end, becomes fluorescent owing to the spatial distance between its fluorophore and quencher components. In the presence of the antibody, however, the clamp-like structure is disturbed by the steric strain-induced distance change between the two antigens, and the fluorescence signal decreases (Figure 12). Through this process, the antibody-powered DNA nanomachine enables the rapid and highly specific detection of three different target antibodies on the nanomolar scale. In addition, steric strain-induced strategies have been introduced into protein sensors utilizing the binding-induced dissociation of kissing loops [98].

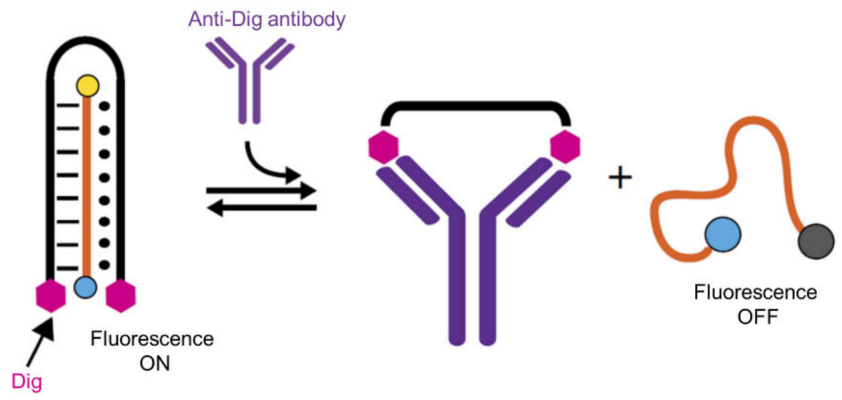

Figure 12. Conceptual scheme of antibody-powered DNA nanomachine capable of antibody detection [97]. 


\section{Biosensors Based on Multivalent Binding Modes}

Because nucleic acids, especially DNA, can form diverse 2D or 3D nanostructures that serve as powerful scaffolds for multiple ligand arrays, many types of multivalent binding systems have been constructed $[1,7,99]$. Therefore, biosensors based on multivalent interactions have been developed. Compared with bivalent interaction-based sensors, multivalent-based sensors are relatively complex systems with the aim of displaying ligands on nucleic acid scaffolds rather than producing signals. In this section, strategies for designing two types of multivalent biosensors are described: biosensors based on (1) DNA chain elongation and (2) DNA nanostructures.

\subsection{Biosensors Based on DNA Chain Elongation}

One of the easiest ways to express multiple ligands using nucleic acids is to linearly connect numerous ligand-modified oligonucleotides with certain distances of one another. To achieve such chain elongation, the DNA HCR is a powerful tool. In 2016, Ma et al. utilized a DNA-programmed HCR for the construction of multivalent binding scaffolds bearing cell-binding aptamers and quantum dots (QDs) to detect target cancer cells [100]. To build such scaffolds, two metastable HCR hairpins were prepared. Each hairpin possesses an overhang to which QD-modified DNA or an aptamer can hybridize (Figure 13). In the presence of an initiator, HCR occurs, and the desired QD-aptamer polymers (QAPs) with multiple aptamers are obtained. As expected, the QAPs showed photoluminescence signals that were four times stronger than those of QD-aptamer monomers (QAMs). Furthermore, the QAPs afforded clearer fluorescence images of target cells (CCRF-CEM) than the QAMs owing to their multivalent binding properties and multi-QD-based signal amplification. This study suggests that the HCR strategy is advantageous for the design of multivalent interaction-based biosensors in terms of target selectivity and detection sensitivity. Recently, this method has been used to detect circulating tumor cells [101,102].

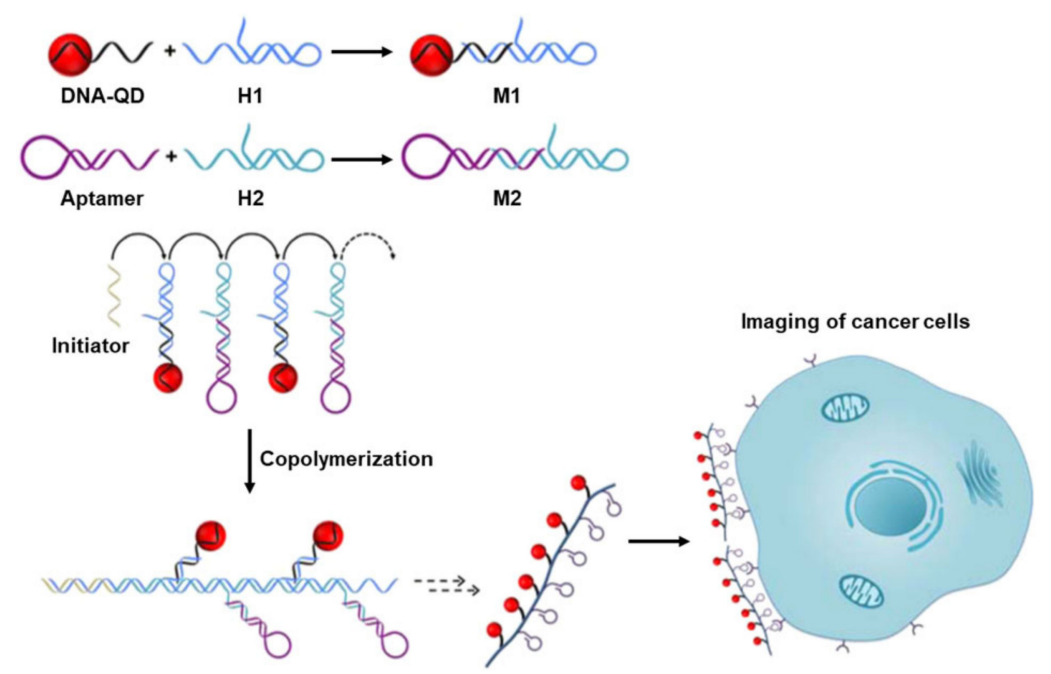

Figure 13. Construction of QD-aptamer polymers (QAPs) via an HCR-based strategy for cancer cell detection. Adapted with permission from Anal. Chem. 2016, 88, 9355-9358, doi:10.1021/acs.analchem.6b02864. Copyright (2016) American Chemical Society [100].

In the same year, Zhang and Zhou introduced the RCA strategy [103] and molecular beacons for the efficient detection of B16 cells [104]. RCA is a DNA amplification technique that utilizes circular templates and polymerases to produce a long single-stranded DNA of a repetitive sequence [105]. In this work, linear-type long-chain DNA structures were obtained through RCA polymerization with Phi29 polymerase, and the fixed complementary DNA (FC DNA) and beacon-type nucleolin aptamers were alternatively hybridized to the RCA products. Subsequently, this complex bound to cells via multiple nucleolin-aptamer interactions and allowed for the very sensitive detection of B16 cells with increased signal 
intensity (Figure 14). Both the unfolding ability and fluorescence intensity of the molecular beacons were significantly improved by RCA polymerization compared to those of the short single-chain system. Because RCA is a simple and practical method, this strategy for multivalent systems can be directly applied to various nucleic acid-based sensory studies and clinical diagnostics of cancer cells.

(A) The signal amplification of molecular beacon

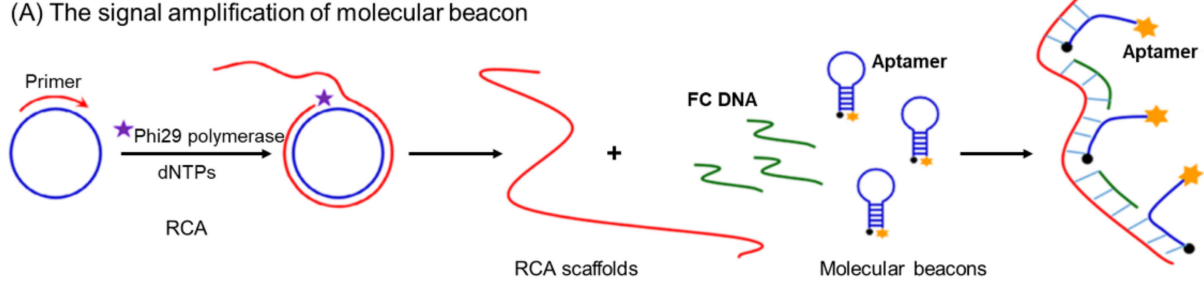

(B) Detection of B16 cells

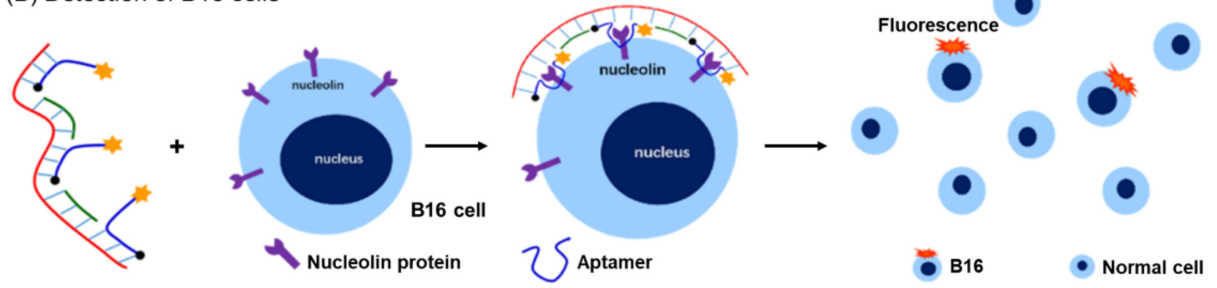

Figure 14. (A) Construction of a multivalent binding scaffold using the rolling circle amplification (RCA), fixed complementary (FC) DNAs, and molecular beacon-type aptamers. (B) Detection of B16 cells using the designed multivalent binding scaffolds. Adapted with permission from ACS Biomater. Sci. Eng. 2020, 6, 3114-3121, doi:10.1021/acsbiomaterials.0c00288. Copyright (2020) American Chemical Society [104].

In addition to these examples, the nucleic acid elongation concept has been used for other designs. For example, CEM cells have been recognized and visualized using DNA nanowires [106], and nanocentipedes have been constructed using the HCR for the imaging of specific cells (SMMC-7721 cells) [107].

\subsection{Biosensors Based on DNA Nanostructures}

Owing to their rigidity arising from their double helix structure, DNA nanostructures with specific shapes have emerged as scaffolds for multivalent interactions of biosensors. Various recognition systems have been designed by introducing aptamers [15,99,108-110] or ligands [111,112] into specific positions of 2D or 3D DNA nanostructures such as DNA origami, tiles, and tetrahedral nanostructures capable of a trivalent binding [7,18,82,113-118].

For instance, in 2021, Tan et al. developed a cell surface imaging system based on a nanoarchitecture that mimics the behavior of membrane proteins [119]. In this study, a T-cho3 DNA nanoscaffold was designed to interact with cell membranes. This nanoscaffold has a pendant DNA probe and three cholesterol tags and forms a tetrahedral structure through the self-assembly of four DNA oligonucleotides; as such, it binds to cell membranes through trivalent binding and has been applied to stimuli-responsive cell imaging. Without potassium ion stimulation, the pendant DNA probe is blocked by the ATP aptamer, whereas when potassium ions stimulate the cell to secrete ATP, the ATP aptamer is released, and the pendant DNA probe then exists in a free form that initiates the HCR for the fluorescent imaging of cells (Figure 15). Furthermore, such molecular-recognition-initiated DNA assembly can be utilized as a scaffold for multivalent interactions in cell membranes. This allows the design of a system that can observe and manipulate cell-to-cell interactions using stimuli [120]. 


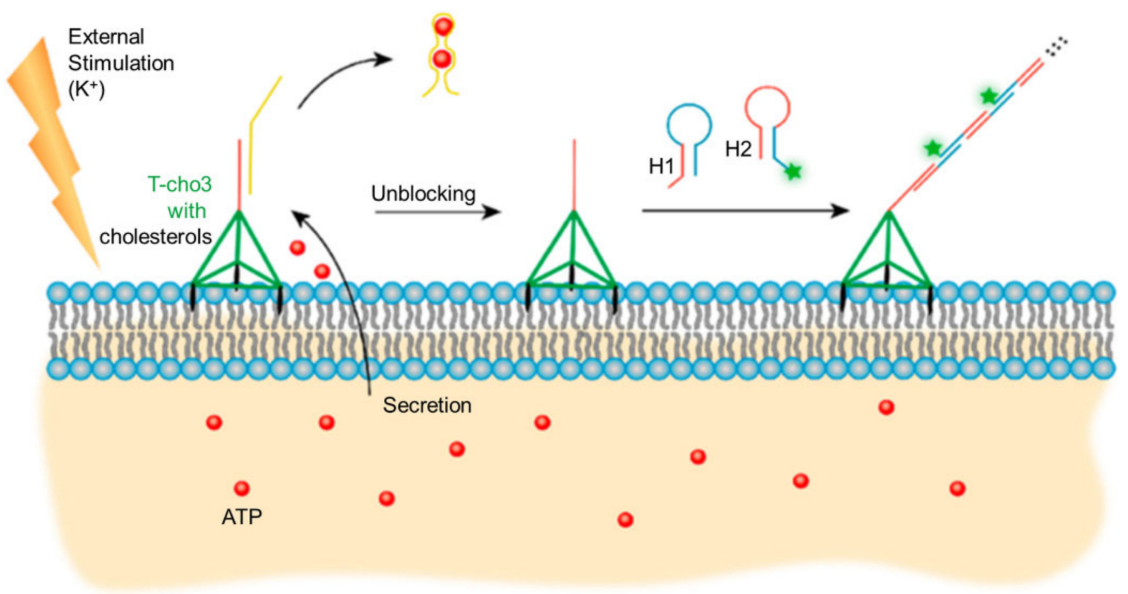

Figure 15. Scheme for trivalent binding of DNA nanoscaffolds to cell membranes and the construction of DNA nanoassemblies for fluorescent imaging. Adapted with permission from J. Am. Chem. Soc. 2021, 143, 4585-4592, doi:10.1021/jacs.0c11245. Copyright (2021) American Chemical Society [119].

In the same year, $\mathrm{Li}$ and co-workers developed an $\mathrm{H}^{+} / \mathrm{K}^{+}$dual-responsive logic sensory system that operates on the surface of cancer cells [121]. The main strategy of this work involves an in situ dimeric framework nucleic acid (FNA) assembly on the cell surface. To this end, two different tetrahedral DNA nanostructures (TDNs) bearing three cholesterols at each of their three vertices were designed for multivalent interactions (Figure 16). These two TDNs also contain an i-motif-forming sequence and a branching strand for further hybridization at their remaining vertex; the branching strand in one of the TDNs is blocked by aptamer AS1411. Once the TDNs are positioned on the cell membrane, as directed by cholesterol molecules, they can be linked to each other under certain conditions to produce signals. Low $\mathrm{pH}$ enables TDNs to assemble into dimeric nanostructures via i-motif formation, and $\mathrm{K}^{+}$ions promote hybridization between the branching strands of TDNs by inducing a G-quadruplex formation of aptamer AS1411. Thus, only in the presence of both $\mathrm{H}^{+}$and $\mathrm{K}^{+}$can the two TDNs form stable dimeric assemblies by proximity-induced hybridization, which produces a förster resonance energy transfer (FRET) signal (Figure 16). Using this concept, an ion-responsive logic sensor was developed. This study demonstrates that multivalent binding scaffolds constructed using DNA nanostructures are useful for sensors that probe extracellular environments.

Recently, trivalent binding based on 3D nanostructures has also been applied to other systems for imaging cancer cells [122-125]. For instance, the trivalent binding signals of tetrahedral structures have been amplified by RCA for the clear visualization of Tcells [126]. Additionally, a DNA framework sensor was developed for the $\mathrm{pH}$ analysis of cell surfaces [127], and the response of tetrahedral nanoprobes to $\mathrm{pH}$ variation has been applied to image exocytosis and retrieve synaptic vesicles [128].

In 2020, an important approach to multivalent systems was reported by Kwon et al. [129]; namely, they designed various multivalent DNA architectures and applied them to pattern recognition for viral sensing and inhibition. To develop multivalent agents that selectively recognize a specific virus, the authors suggested a strategy based on a precisely designed DNA architecture mimicking the unique spatial patterns of antigens expressed on the surface of the virus. By adopting this strategy, a star-shaped DNA architecture was found to be the best motif for targeting the dengue virus (DENV) (Figure 17, top). A viral sensor was designed based on this star shape; it comprises aptamers at every vertex that recognize each DENV epitope as well as five molecular beacon-like motifs on each side of its inner pentagon structure. This structural design allowed for a "steric strain-induced distance change" strategy to be used for fluorescence signal gain upon virus binding (Figure 17, bottom). As a result, the viral sensor constructed from a star-shaped DNA architecture provided high DENV-binding affinity and fluorescence signal enhancement. Additionally, 
DENV was highly inhibited by the star-shaped DNA architecture. This study clearly shows that precisely designed DNA nanoarchitectures are very powerful scaffolds for the construction of biosensors with enhanced selectivity and sensitivity; consequently, this strategy could be utilized for combating other disease-causing pathogens by generating the requisite ligand patterns on target DNA nanoarchitectures.

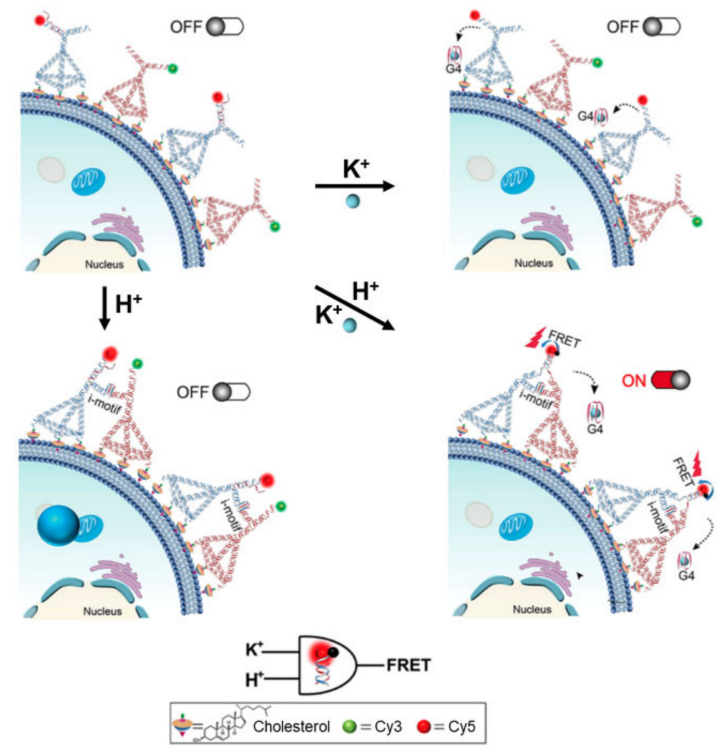

Figure 16. Principle of an ion-responsive logic sensor based on tetrahedral DNA nanostructures. Förster resonance energy transfer (FRET) signals between Cy3 and Cy5 are observed only in the presence of both $\mathrm{K}^{+}$and $\mathrm{H}^{+}$ions. Adapted with permission from Anal. Chem. 2020, 92, 9273-9280, doi:10.1021/acs.analchem.0c01612. Copyright (2020) American Chemical Society [121].
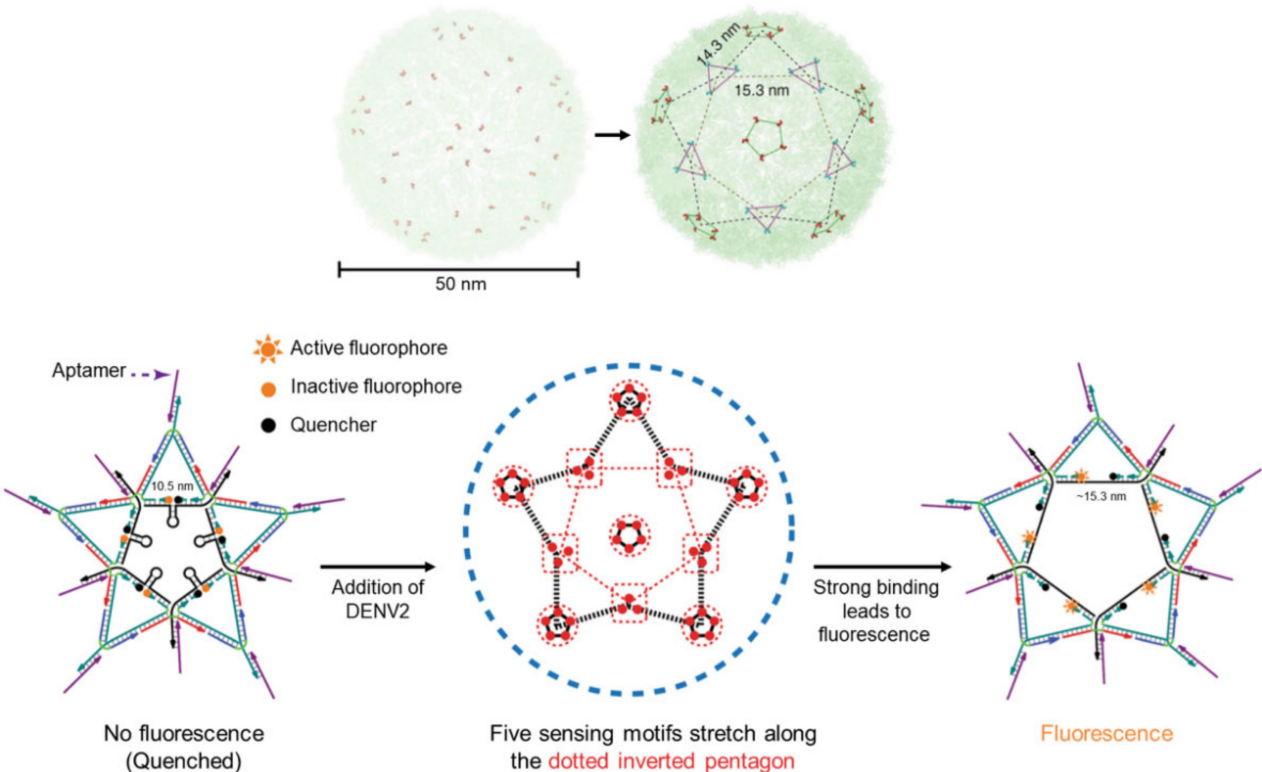

Fluorescence

Figure 17. (top) A star motif found in spatial patterns of epitopes of the dengue virus (DENV). (bottom) Design strategy of a DENV-targeting sensor based on a star-shaped DNA nanoarchitecture. Reprinted by permission from Springer Nature Ltd.: Nat. Chem. 2020, 12, 26-35, doi:10.1038/s41557019-0369-8. Copyright (2020) [129].

\section{Conclusions and Outlook}

In this review, the design strategies and applications of biosensors based on the bivalent and multivalent interactions of nucleic acid scaffolds were explored. These scaffolds 
exhibit several advantageous features, such as rigidity, structural diversity, and an ability to easily conjugate ligands at specific positions and precisely controlled distances; consequently, biosensors with enhanced specificity and sensitivity have been designed to detect and visualize diverse biologically relevant components, mainly proteins and cells. Since this review primarily described strategies for transducing binding events into observable signals, the biosensors described herein were categorized by the manner in which their nucleic acid scaffolds respond structurally to bivalent or multivalent interactions; these include proximity-induced hybridization or DNA strand displacement for bivalent interactions and chain elongation or nanostructure formation for multivalent interactions. Based on the examples presented here, we have proposed general strategies for designing bi- or multivalent biosensors.

In the case of biosensors based on bivalent interactions, many examples have been reported owing to the simplicity of their design. The central principle for producing signals from bivalent interactions is changing the state of the nucleic acids involved, namely their structures. For example, the distance between the ligands on the scaffold can be made to be either longer or shorter than that between the two binding sites. In the former case, bivalent interactions bring the nucleic acids in close proximity to generate or release a new activation strand; these generated or released strands serve as starting points for proximity-induced hybridization or strand displacement strategies, respectively (Figure 18A, top). In contrast, steric-strain-induced structural changes are applicable in the latter case (Figure 18A, bottom). This is shown in the work of Ricci's group [97]. The practical design of biosensors is performed by simply adding signaling molecules to specific positions of nucleic acids. Moreover, the activation strand produced by bivalent recognition would be able to conjugate with any kind of DNA nanodevice or enzymatic amplification system to devise ultrasensitive biosensors with significantly low detection thresholds.

(A) Design strategies for bivalent interactions

(B) Design strategies for multivalent interactions

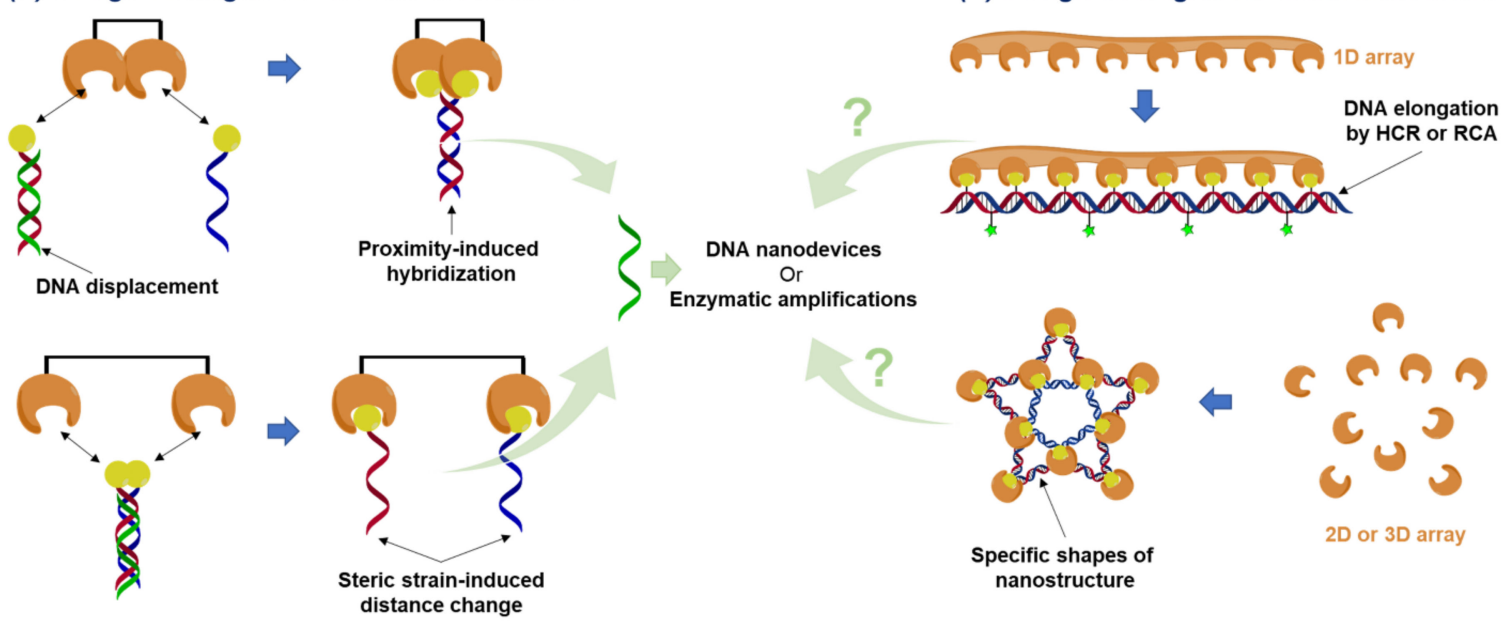

Figure 18. General strategies for designing (A) bivalent or (B) multivalent biosensors.

Multivalent interactions are commonly observed among proteins, viruses, and cell-tocell interactions. Since the binding sites of such biomolecules are usually spread throughout 3D space, not 2D space, the construction of a multiple-ligand display that compliments the size, pattern, and shape of a receptor array is an essential task for the design of biosensors. To this end, two predominant strategies can be utilized to achieve multivalent recognition via nucleic acid scaffolds: one is chain elongation, and the other is the use of DNA nanostructures. The chain elongation strategy is adopted for the recognition of randomly distributed and fluid biomolecule receptors. Since the goal of this strategy is mainly focused on the construction of supramolecules bearing many ligands, nucleic acid techniques capable of making long stretches of nucleic acids from small nucleic acid units, such as HCRs and RCA, are the subject of consideration for building multivalent constructs 
(Figure 18B, top). On the other hand, when receptors are positioned in a specific array, a DNA nanostructure would be advantageous for the construction of multivalent interactions; various architectures have been constructed using nucleic acids. Likewise, a nanostructure can be designed with a geometry in which its vertices can serve as possible positions of target receptors (Figure 18B, bottom). Once this geometry is determined, biosensors for multivalent interactions could be readily constructed by adopting the same signaling strategies utilized for fabricating bivalent-based biosensors (e.g., common fluorescentlabeling or steric strain-induced structural change).

Based on these general strategies, as shown in this review, a wide range of nucleic acid-based multivalent biosensors have been developed to possess advantageous features such as strong binding affinity to targets, high target specificity, and strong signal amplification. However, many challenges remain, and various aspects of this field still require exploration. First, numerous biological molecules capable of bivalent or multivalent interactions have not yet been explored in regard to their use in the design of biosensors [130-135]. Second, precisely designed nanostructures are required for biosensors, particularly those used for detecting viruses; this is because they express unique patterns of antigen arrays. Consequently, biosensors employing multiple ligand arrays with controlled ligand-ligand distances and shapes are greatly desired. However, to date, only a few examples of such biosensors have been reported; these use DNA nanostructures with complex shapes $[129,136]$. Finally, multivalent recognition systems are rarely conjugated with other nanodevice systems for amplification. Even if the multivalent interactions of a biosensor provide it with strong binding affinity and selectivity to its targets, the one-to-one binding between a ligand display and a target still requires extremely high sensitivity. Therefore, the combination of activation strands resulting from multivalent recognition with a wide range of DNA nanodevices could be a promising solution for such limitations.

Accordingly, efforts should be directed toward constructing precisely designed, multivalent, nucleic acid scaffold-based biosensors that feature rapid responses, high sensitivities, and good selectivities. With such improved multivalent biosensors, it is expected that a wide range of disease-related biological interactions will be understood in-depth and also that development of more effective drugs, inhibitors, vaccines, and diagnostic kits for multivalent pathogens (e.g., viruses) will be accelerated in the next decade.

Author Contributions: H.K., H.C. and Y.H. contributed equally to this work. H.K., H.C., C.K. and K.T.K. summarized biosensors based on bivalent binding modes. Y.H., M.K. and K.T.K. summarized biosensors based on multivalent binding modes. All authors helped prepare and write the manuscript. All authors have read and agreed to the published version of the manuscript.

Funding: This work was supported by the National Research Foundation of Korea (NRF) grant funded by the Korean government (MSIT) (No. 2021R1C1C1009199 for K.T.K.).

Institutional Review Board Statement: Not applicable.

Informed Consent Statement: Not applicable.

Data Availability Statement: Not applicable.

Conflicts of Interest: The authors declare no conflict of interest.

\section{References}

1. Fasting, C.; Schalley, C.A.; Weber, M.; Seitz, O.; Hecht, S.; Koksch, B.; Dernedde, J.; Graf, C.; Knapp, E.W.; Haag, R. Multivalency as a Chemical Organization and Action Principle. Angew. Chem. Int. Ed. 2012, 51, 10472-10498. [CrossRef] [PubMed]

2. Harrison, S.C. Virology. Looking inside adenovirus. Science 2010, 329, 1026-1027. [CrossRef]

3. Bandlow, V.; Liese, S.; Lauster, D.; Ludwig, K.; Netz, R.R.; Herrmann, A.; Seitz, O. Spatial Screening of Hemagglutinin on Influenza A Virus Particles: Sialyl-LacNAc Displays on DNA and PEG Scaffolds Reveal the Requirements for Bivalency Enhanced Interactions with Weak Monovalent Binders. J. Am. Chem. Soc. 2017, 139, 16389-16397. [CrossRef]

4. Kiessling, L.L.; Gestwicki, J.E.; Strong, L.E. Synthetic multivalent ligands as probes of signal transduction. Angew. Chem. Int. Ed. 2006, 45, 2348-2368. [CrossRef] [PubMed]

5. Choi, H.; Jung, Y. Applying Multivalent Biomolecular Interactions for Biosensors. Chem-Eur. J. 2018, 24, 19103-19109. [CrossRef] 
6. Diezmann, F.; Seitz, O. DNA-guided display of proteins and protein ligands for the interrogation of biology. Chem. Soc. Rev. 2011, 40, 5789-5801. [CrossRef] [PubMed]

7. Yeldell, S.B.; Seitz, O. Nucleic acid constructs for the interrogation of multivalent protein interactions. Chem. Soc. Rev. 2020, 49, 6848-6865. [CrossRef]

8. $\quad$ Englund, E.A.; Wang, D.Y.; Fujigaki, H.; Sakai, H.; Micklitsch, C.M.; Ghirlando, R.; Martin-Manso, G.; Pendrak, M.L.; Roberts, D.D.; Durell, S.R.; et al. Programmable multivalent display of receptor ligands using peptide nucleic acid nanoscaffolds. Nat. Commun. 2012, 3, 614. [CrossRef]

9. Abendroth, F.; Bujotzek, A.; Shan, M.; Haag, R.; Weber, M.; Seitz, O. DNA-Controlled Bivalent Presentation of Ligands for the Estrogen Receptor. Angew. Chem. Int. Ed. 2011, 50, 8592-8596. [CrossRef]

10. Dubel, N.; Liese, S.; Scherz, F.; Seitz, O. Exploring the Limits of Bivalency by DNA-Based Spatial Screening. Angew. Chem. Int. Ed. 2019, 58, 907-911. [CrossRef] [PubMed]

11. Eberhard, H.; Diezmann, F.; Seitz, O. DNA as a Molecular Ruler: Interrogation of a Tandem SH2 Domain with Self-Assembled, Bivalent DNA-Peptide Complexes. Angew. Chem. Int. Ed. 2011, 50, 4146-4150. [CrossRef] [PubMed]

12. Singh, Y.; Murat, P.; Defrancq, E. Recent developments in oligonucleotide conjugation. Chem. Soc. Rev. 2010, 39, 2054-2070. [CrossRef] [PubMed]

13. Choi, J.; Majima, T. Conformational changes of non-B DNA. Chem. Soc. Rev. 2011, 40, 5893-5909. [CrossRef] [PubMed]

14. Wilner, O.I.; Willner, I. Functionalized DNA Nanostructures. Chem. Rev. 2012, 112, 2528-2556. [CrossRef]

15. Meng, H.M.; Liu, H.; Kuai, H.L.; Peng, R.Z.; Mo, L.T.; Zhang, X.B. Aptamer-integrated DNA nanostructures for biosensing, bioimaging and cancer therapy. Chem. Soc. Rev. 2016, 45, 2583-2602. [CrossRef] [PubMed]

16. Yu, S.; Chen, T.S.; Zhang, Q.Q.; Zhou, M.R.; Zhu, X.L. Application of DNA nanodevices for biosensing. Analyst 2020, 145, 3481-3489. [CrossRef]

17. Bhatia, D.; Wunder, C.; Johannes, L. Self-assembled, Programmable DNA Nanodevices for Biological and Biomedical Applications. ChemBioChem 2021, 22, 763-778. [CrossRef]

18. Engelen, W.; Janssen, B.M.G.; Merkx, M. DNA-based control of protein activity. Chem. Commun. 2016, 52, 3598-3610. [CrossRef]

19. Fredriksson, S.; Gullberg, M.; Jarvius, J.; Olsson, C.; Pietras, K.; Gustafsdottir, S.M.; Ostman, A.; Landegren, U. Protein detection using proximity-dependent DNA ligation assays. Nat. Biotechnol. 2002, 20, 473-477. [CrossRef]

20. Robinson, P.V.; Tsai, C.T.; de Groot, A.E.; McKechnie, J.L.; Bertozzi, C.R. Glyco-seek: Ultrasensitive Detection of Protein-Specific Glycosylation by Proximity Ligation Polymerase Chain Reaction. J. Am. Chem. Soc. 2016, 138, 10722-10725. [CrossRef] [PubMed]

21. Song, J.Q.; Liu, C.L.; Wang, X.Q.; Xu, B.; Liu, X.M.; Li, Y.; Xia, J.; Li, Y.; Zhang, C.; Li, D.N.; et al. O-GlcNAcylation Quantification of Certain Protein by the Proximity Ligation Assay and Clostridium perfringen OGA(D298N)(CpOGA(D298N)). ACS Chem. Biol. 2021, 16, 1040-1049. [CrossRef] [PubMed]

22. Lin, B.Q.; Tian, T.; Lu, Y.Z.; Liu, D.; Huang, M.J.; Zhu, L.; Zhu, Z.; Song, Y.L.; Yang, C.Y. Tracing Tumor-Derived Exosomal PD-L1 by Dual-Aptamer Activated Proximity-Induced Droplet Digital PCR. Angew. Chem. Int. Ed. 2021, 60, 7582-7586. [CrossRef]

23. Abasiyanik, M.F.; Wolfe, K.; Van Phan, H.; Lin, J.; Laxman, B.; White, S.R.; Verhoef, P.A.; Mutlu, G.M.; Patel, B.; Tay, S. Ultrasensitive digital quantification of cytokines and bacteria predicts septic shock outcomes. Nat. Commun. 2020, $11,2607$. [CrossRef] [PubMed]

24. Gullberg, M.; Gustafsdottir, S.M.; Schallmeiner, E.; Jarvius, J.; Bjarnegard, M.; Betsholtz, C.; Landegren, U.; Fredriksson, S. Cytokine detection by antibody-based proximity ligation. Proc. Natl. Acad. Sci. USA 2004, 101, 8420-8424. [CrossRef] [PubMed]

25. Kim, J.; Hu, J.M.; Sollie, R.S.; Easley, C.J. Improvement of Sensitivity and Dynamic Range in Proximity Ligation Assays by Asymmetric Connector Hybridization. Anal. Chem. 2010, 82, 6976-6982. [CrossRef] [PubMed]

26. Fredriksson, S.; Dixon, W.; Ji, H.; Koong, A.C.; Mindrinos, M.; Davis, R.W. Multiplexed protein detection by proximity ligation for cancer biomarker validation. Nat. Methods 2007, 4, 327-329. [CrossRef] [PubMed]

27. Gustafsdottir, S.M.; Schlingemann, J.; Rada-Iglesias, A.; Schallmeiner, E.; Kamali-Moghaddam, M.; Wadelius, C.; Landegren, U. In vitro analysis of DNA-protein interactions by proximity ligation. Proc. Natl. Acad. Sci. USA 2007, 104, 3067-3072. [CrossRef]

28. Heyduk, T. Practical biophysics: Sensors for rapid detection of biological targets utilizing target-induced oligonucleotide annealing. Biophys. Chem. 2010, 151, 91-95. [CrossRef]

29. Lundberg, M.; Eriksson, A.; Tran, B.; Assarsson, E.; Fredriksson, S. Homogeneous antibody-based proximity extension assays provide sensitive and specific detection of low-abundant proteins in human blood. Nucleic Acids Res. 2011, 39, e102. [CrossRef]

30. Li, G.; Moellering, R.E. A Concise, Modular Antibody-Oligonucleotide Conjugation Strategy Based on Disuccinimidyl Ester Activation Chemistry. ChemBioChem 2019, 20, 1599-1605. [CrossRef]

31. Dovgan, I.; Koniev, O.; Kolodych, S.; Wagner, A. Antibody-Oligonucleotide Conjugates as Therapeutic, Imaging, and Detection Agents. Bioconjug. Chem. 2019, 30, 2483-2501. [CrossRef] [PubMed]

32. Liu, R.; He, L.; Hu, Y.S.; Luo, Z.F.; Zhang, J.J. A serological aptamer-assisted proximity ligation assay for COVID-19 diagnosis and seeking neutralizing aptamers. Chem. Sci. 2020, 11, 12157-12164. [CrossRef] [PubMed]

33. Chen, J.B.; Deng, B.; Wu, P.; Li, F.; Li, X.F.; Le, X.C.; Zhang, H.Q.; Hou, X.D. Amplified binding-induced homogeneous assay through catalytic cycling of analyte for ultrasensitive protein detection. Chem. Commun. 2016, 52, 1816-1819. [CrossRef] [PubMed]

34. Genshaft, A.S.; Li, S.; Gallant, C.J.; Darmanis, S.; Prakadan, S.M.; Ziegler, C.G.K.; Lundberg, M.; Fredriksson, S.; Hong, J.; Regev, A.; et al. Multiplexed, targeted profiling of single-cell proteomes and transcriptomes in a single reaction. Genome Biol. 2016, 17, 188. [CrossRef] [PubMed] 
35. Larssen, P.; Wik, L.; Czarnewski, P.; Eldh, M.; Lof, L.; Ronquist, K.G.; Dubois, L.; Freyhult, E.; Gallant, C.J.; Oelrich, J.; et al. Tracing Cellular Origin of Human Exosomes Using Multiplex Proximity Extension Assays. Mol. Cell. Proteomics 2017, 16, 502-511. [CrossRef] [PubMed]

36. Gidlof, O.; Evander, M.; Rezeli, M.; Marko-Varga, G.; Laurell, T.; Erlinge, D. Proteomic profiling of extracellular vesicles reveals additional diagnostic biomarkers for myocardial infarction compared to plasma alone. Sci. Rep. 2019, 9, 8991. [CrossRef]

37. Yan, S.J.; Ahmad, K.Z.; Li, S.J.; Warden, A.R.; Su, J.; Zhang, Y.; Yu, Y.Y.; Zhi, X.; Ding, X.T. Pre-coated interface proximity extension reaction assay enables trace protein detection with single-digit accuracy. Biosens. Bioelectron. 2021, 183, 113211. [CrossRef] [PubMed]

38. Berggrund, M.; Enroth, S.; Lundberg, M.; Assarsson, E.; Stalberg, K.; Lindquist, D.; Hallmans, G.; Grankvist, K.; Olovsson, M.; Gyllensten, U. Identification of Candidate Plasma Protein Biomarkers for Cervical Cancer Using the Multiplex Proximity Extension Assay. Mol. Cell. Proteomics 2019, 18, 735-743. [CrossRef] [PubMed]

39. Al-Amin, R.A.; Gallant, C.J.; Muthelo, P.M.; Landegren, U. Sensitive Measurement of Drug-Target Engagement by a Cellular Thermal Shift Assay with Multiplex Proximity Extension Readout. Anal. Chem. 2021, 93, 10999-11009. [CrossRef]

40. Rodriguez, L.; Pekkarinen, P.T.; Lakshmikanth, T.; Tan, Z.Y.; Consiglio, C.R.; Pou, C.; Chen, Y.; Mugabo, C.H.; Nguyen, N.A.; Nowlan, K.; et al. Systems-Level Immunomonitoring from Acute to Recovery Phase of Severe COVID-19. Cell Rep. Med. 2020, 1, 100078. [CrossRef] [PubMed]

41. Schueder, F.; Lara-Gutierrez, J.; Haas, D.; Beckwith, K.S.; Yin, P.; Ellenberg, J.; Jungmann, R. Super-Resolution Spatial Proximity Detection with Proximity-PAINT. Angew. Chem. Int. Ed. 2021, 60, 716-720. [CrossRef]

42. Du, M.Y.; Zheng, J.; Tian, S.B.; Liu, Y.C.; Zheng, Z.H.; Wang, H.Z.; Xia, J.B.; Ji, X.H.; He, Z.K. DNAzyme Walker for Homogeneous Detection of Enterovirus EV71 and CVB3. Anal. Chem. 2021, 93, 5606-5611. [CrossRef]

43. Bertucci, A.; Porchetta, A.; Ricci, F. Antibody-Templated Assembly of an RNA Mimic of Green Fluorescent Protein. Anal. Chem. 2018, 90, 1049-1053. [CrossRef] [PubMed]

44. Hu, J.M.; Wang, T.Y.; Kim, J.; Shannon, C.; Easley, C.J. Quantitation of Femtomolar Protein Levels via Direct Readout with the Electrochemical Proximity Assay. J. Am. Chem. Soc. 2012, 134, 7066-7072. [CrossRef] [PubMed]

45. Deng, B.; Chen, J.B.; Zhang, H.Q. Assembly of Multiple DNA Components through Target Binding toward Homogeneous, Isothermally Amplified, and Specific Detection of Proteins. Anal. Chem. 2014, 86, 7009-7016. [CrossRef] [PubMed]

46. Ren, K.W.; Wu, J.; Zhang, Y.; Yan, F.; Ju, H.X. Proximity Hybridization Regulated DNA Biogate for Sensitive Electrochemical Immunoassay. Anal. Chem. 2014, 86, 7494-7499. [CrossRef] [PubMed]

47. Du, H.; Yang, P.; Hou, X.; Hou, X.D.; Chen, J.B. Accelerating DNA nanomotor by branched DNAzyme for ultrasensitive optical detection of thrombin. Microchem. J. 2018, 139, 260-267. [CrossRef]

48. Shen, H.W.; Liu, L.Y.; Yuan, Z.W.; Liu, Q.; Li, B.Y.; Zhang, M.; Tang, H.J.; Zhang, J.; Zhao, S.Q. Novel cytosensor for accurate detection of circulating tumor cells based on a dual-recognition strategy and BSA@Ag@Ir metallic-organic nanoclusters. Biosens. Bioelectron. 2021, 179, 113102. [CrossRef]

49. Zhou, H.; Yu, Q.; Wang, H.Y.; Zhu, W.J.; Liu, J.; Wang, Z.H. A general scattering proximity immunoassay with the formation of dimer of gold nanoparticle. Talanta 2021, 233, 122515. [CrossRef] [PubMed]

50. Li, Y.Y.; Mansour, H.; Watson, C.J.F.; Tang, Y.N.; MacNeil, A.J.; Li, F. Amplified detection of nucleic acids and proteins using an isothermal proximity CRISPR Cas12a assay. Chem. Sci. 2021, 12, 2133-2137. [CrossRef]

51. Zhang, Y.P.; Wang, H.P.; Dong, R.L.; Li, S.Y.; Wang, Z.G.; Liu, S.L.; Pang, D.W. Proximity-induced exponential amplification reaction triggered by proteins and small molecules. Chem. Commun. 2021, 57, 4714-4717. [CrossRef]

52. Pellejero, L.B.; Mahdifar, M.; Ercolani, G.; Watson, J.; Brown, T.; Ricci, F. Using antibodies to control DNA-templated chemical reactions. Nat. Commun. 2020, 11, 6242. [CrossRef]

53. Zhang, H.Q.; Li, X.F.; Le, X.C. Binding-Induced DNA Assembly and Its Application to Yoctomole Detection of Proteins. Anal. Chem. 2012, 84, 877-884. [CrossRef] [PubMed]

54. Li, F.; Zhang, H.Q.; Lai, C.; Li, X.F.; Le, X.C. A Molecular Translator that Acts by Binding-Induced DNA Strand Displacement for a Homogeneous Protein Assay. Angew. Chem. Int. Ed. 2012, 51, 9317-9320. [CrossRef]

55. Liang, H.; Chen, S.; Li, P.P.; Wang, L.P.; Li, J.Y.; Li, J.; Yang, H.H.; Tan, W.H. Nongenetic Approach for Imaging Protein Dimerization by Aptamer Recognition and Proximity-Induced DNA Assembly. J. Am. Chem. Soc. 2018, 140, 4186-4190. [CrossRef] [PubMed]

56. Jiang, Y.L.; Yang, P.; Du, L.J.; Xia, L.Y.; Chen, J.B.; Hou, X.D. A signal conversion system using binding-induced strand displacement for disease biomarker assay. Luminescence 2021, 36, 1483-1490. [CrossRef] [PubMed]

57. Li, C.X.; Lin, R.Y.; Li, T.; Liu, F.; Li, N. The fast detection of streptavidin based on the initial reaction rate of the binding-induced DNA strand-displacement reaction. Anal. Methods 2016, 8, 6701-6704. [CrossRef]

58. Yang, J.M.; Dou, B.T.; Yuan, R.; Xiang, Y. Aptamer/Protein Proximity Binding-Triggered Molecular Machine for Amplified Electrochemical Sensing of Thrombin. Anal. Chem. 2017, 89, 5138-5143. [CrossRef]

59. Yang, J.M.; Dou, B.T.; Yuan, R.; Xiang, Y. Proximity Binding and Metal Ion-Dependent DNAzyme Cyclic Amplification-Integrated Aptasensor for Label-Free and Sensitive Electrochemical Detection of Thrombin. Anal. Chem. 2016, 88, 8218-8223. [CrossRef]

60. Man, Y.; Liu, J.B.; Wu, J.; Yin, L.; Pei, H.; Wu, Q.; Xia, Q.F.; Ju, H.X. An anchored monopodial DNA walker triggered by proximity hybridization for amplified amperometric biosensing of nucleic acid and protein. Anal. Chim. Acta 2020, 1107, 48-54. [CrossRef]

61. Yun, W.; You, L.F.; Li, F.K.; Wu, H.; Chen, L.; Yang, L.Z. Proximity ligation assay induced and DNAzyme powered DNA motor for fluorescent detection of thrombin. Spectrochim. Acta A 2019, 207, 39-45. [CrossRef] [PubMed] 
62. Zhu, J.; Gan, H.Y.; Wu, J.; Ju, H.X. Molecular Machine Powered Surface Programmatic Chain Reaction for Highly Sensitive Electrochemical Detection of Protein. Anal. Chem. 2018, 90, 5503-5508. [CrossRef] [PubMed]

63. Xu, Q.; Liu, K.; Jin, J.J.; Zhang, X.F. Binding-induced output of catalyst DNA for efficient payload of DNAzyme on magnetic beads by catalyzed hairpin assembly. Microchem. J. 2021, 168, 106490. [CrossRef]

64. Zhang, L.; Zhang, K.X.; Liu, G.C.; Liu, M.J.; Liu, Y.; Li, J.H. Label-Free Nanopore Proximity Bioassay for Platelet-Derived Growth Factor Detection. Anal. Chem. 2015, 87, 5677-5682. [CrossRef]

65. Fan, W.; Chen, J.B.; Du, H.; Hu, C.J.; Yang, P.; Hou, X.D. Activation of catalytic DNAzyme by binding-induced DNA displacement for homogeneous assay. Luminescence 2021, 36, 1498-1506. [CrossRef]

66. Tang, Y.A.; Wang, Z.X.; Yang, X.L.; Chen, J.B.; Liu, L.N.; Zhao, W.A.; Le, X.C.; Li, F. Constructing real-time, wash-free, and reiterative sensors for cell surface proteins using binding-induced dynamic DNA assembly. Chem. Sci. 2015, 6, 5729-5733. [CrossRef] [PubMed]

67. Peng, R.Z.; Zheng, X.F.; Lyu, Y.F.; Xu, L.J.; Zhang, X.B.; Ke, G.L.; Liu, Q.L.; You, C.J.; Huan, S.Y.; Tan, W.H. Engineering a 3D DNA-Logic Gate Nanomachine for Bispecific Recognition and Computing on Target Cell Surfaces. J. Am. Chem. Soc. 2018, 140, 9793-9796. [CrossRef]

68. Li, F.; Lin, Y.W.; Le, X.C. Binding-Induced Formation of DNA Three-Way Junctions and Its Application to Protein Detection and DNA Strand Displacement. Anal. Chem. 2013, 85, 10835-10841. [CrossRef]

69. Ren, K.W.; Wu, J.; Yan, F.; Zhang, Y.; Ju, H.X. Immunoreaction-triggered DNA assembly for one-step sensitive ratiometric electrochemical biosensing of protein biomarker. Biosens. Bioelectron. 2015, 66, 345-349. [CrossRef] [PubMed]

70. Du, H.; Yang, P.; Hou, X.; Zhou, R.X.; Hou, X.D.; Chen, J.B. Expanding DNA nanomachine functionality through binding-induced DNA output for application in clinical diagnosis. Chem. Commun. 2019, 55, 3610-3613. [CrossRef] [PubMed]

71. Chen, Z.Q.; Wang, C.; Hao, L.J.; Gao, R.; Li, F.; Liu, S.F. Proximity recognition and polymerase-powered DNA walker for one-step and amplified electrochemical protein analysis. Biosens. Bioelectron. 2019, 128, 104-112. [CrossRef] [PubMed]

72. Bracaglia, S.; Ranallo, S.; Plaxco, K.W.; Ricci, F. Programmable, Multiplexed DNA Circuits Supporting Clinically Relevant, Electrochemical Antibody Detection. ACS Sens. 2021, 6, 2442-2448. [CrossRef]

73. Mocenigo, M.; Porchetta, A.; Rossetti, M.; Brass, E.; Tonini, L.; Puzzi, L.; Tagliabue, E.; Triulzi, T.; Marini, B.; Ricci, F.; et al. Rapid, Cost-Effective Peptide/Nucleic Acid-Based Platform for Therapeutic Antibody Monitoring in Clinical Samples. ACS Sens. 2020, 5, 3109-3115. [CrossRef]

74. Porchetta, A.; Ippodrino, R.; Marini, B.; Caruso, A.; Caccuri, F.; Ricci, F. Programmable Nucleic Acid Nanoswitches for the Rapid, Single-Step Detection of Antibodies in Bodily Fluids. J. Am. Chem. Soc. 2018, 140, 947-953. [CrossRef] [PubMed]

75. Wang, B.; Shi, S.W.; Yang, X.L.; Wang, Y.; Qi, H.L.; Gao, Q.; Zhang, C.X. Separation-Free Electrogenerated Chemiluminescence Immunoassay Incorporating Target Assistant Proximity Hybridization and Dynamically Competitive Hybridization of a DNA Signal Probe. Anal. Chem. 2020, 92, 884-891. [CrossRef]

76. Yang, X.L.; Liu, W.H.; Chan, D.C.H.; Ahmed, S.U.; Wang, H.; Wang, Z.; Nemr, C.R.; Kelley, S.O. Fluorescent Droplet Cytometry for On-Cell Phenotype Tracking. J. Am. Chem. Soc. 2020, 142, 14805-14809. [CrossRef] [PubMed]

77. Li, N.X.; Du, M.Y.; Liu, Y.C.; Ji, X.H.; He, Z.K. Multipedal DNA Walker Biosensors Based on Catalyzed Hairpin Assembly and Isothermal Strand-Displacement Polymerase Reaction for the Chemiluminescent Detection of Proteins. ACS Sens. 2018, 3, 1283-1290. [CrossRef] [PubMed]

78. Tian, Y.S.; Xin, C.; Liu, S.; Liu, Y.; Liu, S.F. Affinity Binding-Induced $\mathrm{Hg}^{2+}$ Release and Quantum Dot Doping for General, Label-Free, and Homogenous Fluorescence Protein Assay. ACS Sens. 2018, 3, 1401-1408. [CrossRef] [PubMed]

79. Li, F.; Lin, Y.W.; Lau, A.; Tang, Y.N.; Chen, J.B.; Le, X.C. Binding-Induced Molecular Amplifier as a Universal Detection Platform for Biomolecules and Biomolecular Interaction. Anal. Chem. 2018, 90, 8651-8657. [CrossRef]

80. Gan, H.Y.; Wu, J.; Ju, H.X. Proximity hybridization-induced on particle DNA walker for ultrasensitive protein detection. Anal. Chim. Acta 2019, 1074, 142-149. [CrossRef]

81. Qing, M.; Sun, Z.; Wang, L.; Du, S.Z.; Zhou, J.; Tang, Q.; Luo, H.Q.; Li, N.B. CRISPR/Cas12a-regulated homogeneous electrochemical aptasensor for amplified detection of protein. Sens. Actuators B Chem. 2021, 348, 130713. [CrossRef]

82. Kong, G.Z.; Zhang, M.; Xiong, M.Y.; Fu, X.Y.; Ke, G.L.; Zhang, X.B. DNA nanostructure-based fluorescent probes for cellular sensing. Anal. Methods 2020, 12, 1415-1429. [CrossRef]

83. Li, F.; Zhang, H.Q.; Wang, Z.X.; Li, X.K.; Li, X.F.; Le, X.C. Dynamic DNA Assemblies Mediated by Binding-Induced DNA Strand Displacement. J. Am. Chem. Soc. 2013, 135, 2443-2446. [CrossRef] [PubMed]

84. Xiong, E.H.; Zhen, D.S.; Jiang, L.; Zhou, X.M. Binding-Induced 3D-Bipedal DNA Walker for Cascade Signal Amplification Detection of Thrombin Combined with Catalytic Hairpin Assembly Strategy. Anal. Chem. 2019, 91, 15317-15324. [CrossRef]

85. Li, X.L.; Wu, Y.Y.; Niu, J.J.; Jiang, D.G.; Xiao, D.; Zhou, C.S. One-step sensitive thrombin detection based on a nanofibrous sensing platform. J. Mater. Chem. B 2019, 7, 5161-5169. [CrossRef]

86. Hua, X.Y.; Zheng, T.; Zhao, J.M.; Xu, W.J. Recycling of Proximity Binding-Based DNA Architecture Driven by Hairpin Strand Displacement for Amplified Electrochemical Aptasensor. J. Electrochem. Soc. 2019, 166, B1689-B1694. [CrossRef]

87. Tang, Y.N.; Lin, Y.W.; Yang, X.L.; Wang, Z.X.; Le, X.C.; Li, F. Universal Strategy To Engineer Catalytic DNA Hairpin Assemblies for Protein Analysis. Anal. Chem. 2015, 87, 8063-8066. [CrossRef] [PubMed]

88. Engelen, W.; Meijer, L.H.H.; Somers, B.; de Greef, T.F.A.; Merkx, M. Antibody-controlled actuation of DNA-based molecular circuits. Nat. Commun. 2017, 8, 14473. [CrossRef] 
89. Liu, J.; Lai, T.; Mu, K.J.; Zhou, Z. Strip biosensor for amplified detection of nerve growth factor-beta based on a molecular translator and catalytic DNA circuit. Analyst 2014, 139, 4874-4878. [CrossRef] [PubMed]

90. Chang, X.; Zhang, C.; Lv, C.; Sun, Y.; Zhang, M.Z.; Zhao, Y.M.; Yang, L.L.; Han, D.; Tan, W.H. Construction of a Multiple-AptamerBased DNA Logic Device on Live Cell Membranes via Associative Toehold Activation for Accurate Cancer Cell Identification. J. Am. Chem. Soc. 2019, 141, 12738-12743. [CrossRef]

91. Bi, S.; Yue, S.Z.; Zhang, S.S. Hybridization chain reaction: A versatile molecular tool for biosensing, bioimaging, and biomedicine. Chem. Soc. Rev. 2017, 46, 4281-4298. [CrossRef] [PubMed]

92. Qiu, F.; Gan, X.Y.; Jiang, B.Y.; Yuan, R.; Xiang, Y. Electrode immobilization-free and sensitive electrochemical sensing of thrombin via magnetic nanoparticle-decorated DNA polymers. Sens. Actuators B Chem. 2021, 331, 129395. [CrossRef]

93. Du, M.Y.; Mao, G.B.; Tian, S.B.; Liu, Y.C.; Zheng, J.; Ke, X.L.; Zheng, Z.H.; Wang, H.Z.; Ji, X.H.; He, Z.K. Target-Induced Cascade Amplification for Homogeneous Virus Detection. Anal. Chem. 2019, 91, 15099-15106. [CrossRef]

94. Li, N.; Liu, L.; Xiang, M.H.; Liu, J.W.; Yu, R.Q.; Jiang, J.H. Proximity- induced hybridization chain assembly with small- molecule linked DNA for single- step amplified detection of antibodies. Chem. Commun. 2019, 55, 4387-4390. [CrossRef] [PubMed]

95. Ranallo, S.; Rossetti, M.; Plaxco, K.W.; Vallee-Belisle, A.; Ricci, F. A Modular, DNA-Based Beacon for Single-Step Fluorescence Detection of Antibodies and Other Proteins. Angew. Chem. Int. Ed. 2015, 54, 13214-13218. [CrossRef] [PubMed]

96. Pfeiffer, M.; Trofymchuk, K.; Ranallo, S.; Ricci, F.; Steiner, F.; Cole, F.; Glembockyte, V.; Tinnefeld, P. Single antibody detection in a DNA origami nanoantenna. iScience 2021, 24, 103072. [CrossRef]

97. Ranallo, S.; Prevost-Tremblay, C.; Idili, A.; Vallee-Belisle, A.; Ricci, F. Antibody-powered nucleic acid release using a DNA-based nanomachine. Nat. Commun. 2017, 8, 1-9. [CrossRef]

98. Tian, Y.S.; Zhang, S.S.; Wang, L.; Liu, S.F. A Modular Nanoswitch for Mix-and-Detect Protein Assay Based on Binding-Induced Cascade Dissociation of Kissing Complex. ChemBioChem 2018, 19, 716-722. [CrossRef] [PubMed]

99. Vorobyeva, M.; Vorobjev, P.; Venyaminova, A. Multivalent Aptamers: Versatile Tools for Diagnostic and Therapeutic Applications. Molecules 2016, 21, 1613. [CrossRef] [PubMed]

100. Li, Z.; He, X.W.; Luo, X.C.; Wang, L.; Ma, N. DNA-Programmed Quantum Dot Polymerization for Ultrasensitive Molecular Imaging of Cancer Cells. Anal. Chem. 2016, 88, 9355-9358. [CrossRef]

101. Li, Z.; Wang, G.L.; Shen, Y.; Guo, N.N.; Ma, N. DNA-Templated Magnetic Nanoparticle-Quantum Dot Polymers for Ultrasensitive Capture and Detection of Circulating Tumor Cells. Adv. Funct. Mater. 2018, 28, 1707152. [CrossRef]

102. Ding, C.P.; Zhang, C.L.; Yin, X.Y.; Cao, X.Y.; Cai, M.F.; Xian, Y.Z. Near-Infrared Fluorescent Ag $_{2}$ S Nanodot-Based Signal Amplification for Efficient Detection of Circulating Tumor Cells. Anal. Chem. 2018, 90, 6702-6709. [CrossRef] [PubMed]

103. Zhang, Z.Q.; Ali, M.M.; Eckert, M.A.; Kang, D.K.; Chen, Y.Y.; Sender, L.S.; Fruman, D.A.; Zhao, W.A. A polyvalent aptamer system for targeted drug delivery. Biomaterials 2013, 34, 9728-9735. [CrossRef]

104. Zhang, Z.Q.; Wang, S.S.; Ma, J.; Zhou, T.; Wang, F.; Wang, X.F.; Zhang, G.D. Rolling Circle Amplification-Based Polyvalent Molecular Beacon Probe-Assisted Signal Amplification Strategies for Sensitive Detection of B16 Cells. ACS Biomater. Sci. Eng. 2020, 6, 3114-3121. [CrossRef] [PubMed]

105. Zhao, Y.X.; Chen, F.; Li, Q.; Wang, L.H.; Fan, C.H. Isothermal Amplification of Nucleic Acids. Chem. Rev. 2015, 115, 12491-12545. [CrossRef]

106. Xue, C.; Zhang, S.B.; Yu, X.; Hu, S.Y.; Lu, Y.; Wu, Z.S. Periodically Ordered, Nuclease-Resistant DNA Nanowires Decorated with Cell-Specific Aptamers as Selective Theranostic Agents. Angew. Chem. Int. Ed. 2020, 59, 17540-17547. [CrossRef] [PubMed]

107. Li, W.S.; Yang, X.H.; He, L.L.; Wang, K.M.; Wang, Q.; Huang, J.; Liu, J.B.; Wu, B.; Xu, C.C. Self-Assembled DNA Nanocentipede as Multivalent Drug Carrier for Targeted Delivery. ACS Appl. Mater. Inter. 2016, 8, 25733-25740. [CrossRef]

108. Krissanaprasit, A.; Key, C.M.; Pontula, S.; LaBean, T.H. Self-Assembling Nucleic Acid Nanostructures Functionalized with Aptamers. Chem. Rev. 2021, 121, 13797-13868. [CrossRef]

109. Liu, X.W.; Yan, H.; Liu, Y.; Chang, Y. Targeted Cell-Cell Interactions by DNA Nanoscaffold-Templated Multivalent Bispecific Aptamers. Small 2011, 7, 1673-1682. [CrossRef] [PubMed]

110. Lin, M.H.; Zhang, J.; Wan, H.; Yan, C.Y.; Xia, F. Rationally Designed Multivalent Aptamers Targeting Cell Surface for Biomedical Applications. ACS Appl. Mater. Interfaces 2021, 13, 9369-9389. [CrossRef]

111. Machida, T.; Novoa, A.; Gillon, E.; Zheng, S.S.; Claudinon, J.; Eierhoff, T.; Imberty, A.; Romer, W.; Winssinger, N. Dynamic Cooperative Glycan Assembly Blocks the Binding of Bacterial Lectins to Epithelial Cells. Angew. Chem. Int. Ed. 2017, 56, 6762-6766. [CrossRef]

112. Chidchob, P.; Offenbartl-Stiegert, D.; McCarthy, D.; Luo, X.; Li, J.N.; Howorka, S.; Sleiman, H.F. Spatial Presentation of Cholesterol Units on a DNA Cube as a Determinant of Membrane Protein-Mimicking Functions. J. Am. Chem. Soc. 2019, 141, 1100-1108. [CrossRef]

113. Huang, D.; Patel, K.; Perez-Garrido, S.; Marshall, J.F.; Palma, M. DNA Origami Nanoarrays for Multivalent Investigations of Cancer Cell Spreading with Nanoscale Spatial Resolution and Single-Molecule Control. ACS Nano 2019, 13, 728-736. [CrossRef] [PubMed]

114. Krissanaprasit, A.; Key, C.M.; Froehlich, K.; Pontula, S.; Mihalko, E.; Dupont, D.M.; Andersen, E.S.; Kjems, J.; Brown, A.C.; LaBean, T.H. Multivalent Aptamer-Functionalized Single-Strand RNA Origami as Effective, Target-Specific Anticoagulants with Corresponding Reversal Agents. Adv. Healthc. Mater. 2021, 10, 2001826. [CrossRef] 
115. Wang, Z.Y.; Sun, P.C.; Su, J.J.; Zhang, N.; Gu, H.Z.; Zhao, Y.X. DNA nanotechnology-facilitated ligand manipulation for targeted therapeutics and diagnostics. J. Control. Release 2021, 340, 292-307. [CrossRef] [PubMed]

116. Rinker, S.; Ke, Y.G.; Liu, Y.; Chhabra, R.; Yan, H. Self-assembled DNA nanostructures for distance-dependent multivalent ligand-protein binding. Nat. Nanotechnol. 2008, 3, 418-422. [CrossRef]

117. Yang, F.; Li, Q.; Wang, L.H.; Zhang, G.J.; Fan, C.H. Framework-Nucleic-Acid-Enabled Biosensor Development. ACS Sens. 2018, 3 , 903-919. [CrossRef] [PubMed]

118. Shaw, A.; Lundin, V.; Petrova, E.; Fordos, F.; Benson, E.; Al-Amin, A.; Herland, A.; Blokzijl, A.; Hogberg, B.; Teixeira, A.I. Spatial control of membrane receptor function using ligand nanocalipers. Nat. Methods 2014, 11, 841-846. [CrossRef] [PubMed]

119. Li, J.; Xun, K.Y.; Zheng, L.Y.; Peng, X.Y.; Qiu, L.P.; Tan, W.H. DNA-Based Dynamic Mimicry of Membrane Proteins for Programming Adaptive Cellular Interactions. J. Am. Chem. Soc. 2021, 143, 4585-4592. [CrossRef] [PubMed]

120. Xun, K.Y.; Pei, K.; Liu, X.J.; Peng, X.Y.; Du, Y.L.; Qiu, L.P.; Tan, W.H. Cell-Membrane-Anchored DNA Nanoplatform for Programming Cellular Interactions. J. Am. Chem. Soc. 2019, 141, 18013-18020.

121. Peng, P.; Wang, Q.W.; Du, Y.; Wang, H.H.; Shi, L.L.; Li, T. Extracellular Ion-Responsive Logic Sensors Utilizing DNA Dimeric Nanoassemblies on Cell Surface and Application to Boosting AS1411 Internalization. Anal. Chem. 2020, 92, 9273-9280. [CrossRef] [PubMed]

122. Jiang, D.W.; Sun, Y.H.; Li, J.; Li, Q.; Lv, M.; Zhu, B.; Tian, T.; Cheng, D.F.; Xia, J.Y.; Zhang, L.; et al. Multiple-Armed Tetrahedral DNA Nanostructures for Tumor-Targeting, Dual-Modality in Vivo Imaging. ACS Appl. Mater. Interfaces 2016, 8, 4378-4384. [CrossRef] [PubMed]

123. Song, L.L.; Wang, Z.R.; Liu, J.B.; Wang, T.; Jiang, Q.; Ding, B.Q. Tumor-Targeted DNA Bipyramid for in Vivo Dual -Modality Imaging. ACS Appl. Bio Mater. 2020, 3, 2854-2860. [CrossRef]

124. Li, M.; Ding, H.M.; Lin, M.H.; Yin, F.F.; Song, L.; Mao, X.H.; Li, F.; Ge, Z.L.; Wang, L.H.; Zuo, X.L.; et al. DNA FrameworkProgrammed Cell Capture via Topology-Engineered Receptor-Ligand Interactions. J. Am. Chem. Soc. 2019, 141, 18910-18915. [CrossRef]

125. Gao, Y.; Li, Q.; Zhang, J.; Wu, C.; Shen, Z.; Xue, C.; Chang, H.T.; Wu, Z.S. Bead-String-Shaped DNA Nanowires with Intrinsic Structural Advantages and Their Potential for Biomedical Applications. ACS Appl. Mater. Inter. 2020, 12, 3341-3353. [CrossRef] [PubMed]

126. Zhang, Z.Y.; Liu, Q.J.; Tan, J.Z.; Zhan, X.X.; Liu, T.; Wang, Y.T.; Lu, G.; Wu, M.H.; Zhang, Y.Q. Coating with flexible DNA network enhanced T-cell activation and tumor killing for adoptive cell therapy. Acta Pharm. Sin. B. 2021, 11, 1965-1977. [CrossRef]

127. Liu, J.X.; Li, W.W.; Li, R.S.; Yin, X.Z.; He, S.L.; Hu, J.Q.; Ruan, S.C. Programmable DNA Framework Sensors for In Situ Cell-Surface pH Analysis. Anal. Chem. 2021, 93, 12170-12174. [CrossRef]

128. Liu, C.; Huang, Z.K.; Jiang, W.; Liu, X.J.; Li, J.; Han, X.Y.; Tu, H.J.; Qiu, L.P.; Tan, W.H. Programmable pH-Responsive DNA Nanosensors for Imaging Exocytosis and Retrieval of Synaptic Vesicles. Anal. Chem. 2020, 92, 3620-3626. [CrossRef] [PubMed]

129. Kwon, P.S.; Ren, S.; Kwon, S.J.; Kizer, M.E.; Kuo, L.; Xie, M.; Zhu, D.; Zhou, F.; Zhang, F.M.; Kim, D.; et al. Designer DNA architecture offers precise and multivalent spatial pattern-recognition for viral sensing and inhibition. Nat. Chem. 2020, 12, 26-35. [CrossRef]

130. Bandlow, V.; Lauster, D.; Ludwig, K.; Hilsch, M.; Reiter-Scherer, V.; Rabe, J.P.; Bottcher, C.; Herrmann, A.; Seitz, O. Sialyl-LacNAcPNA DNA Concatamers by Rolling-Circle Amplification as Multivalent Inhibitors of Influenza A Virus Particles. ChemBioChem 2019, 20, 159-165. [CrossRef] [PubMed]

131. Bachem, G.; Wamhoff, E.C.; Silberreis, K.; Kim, D.; Baukmann, H.; Fuchsberger, F.; Dernedde, J.; Rademacher, C.; Seitz, O. Rational Design of a DNA-Scaffolded High-Affinity Binder for Langerin. Angew. Chem. Int. Ed. 2020, 59, 21016-21022. [CrossRef]

132. Matsuura, K.; Hibino, M.; Yamada, Y.; Kobayashi, K. Construction of glyco-clusters by self-organization of site-specifically glycosylated oligonucleotides and their cooperative amplification of lectin-recognition. J. Am. Chem. Soc. 2001, 123, 357-358. [CrossRef] [PubMed]

133. Gorska, K.; Huang, K.T.; Chaloin, O.; Winssinger, N. DNA-Templated Homo- and Heterodimerization of Peptide Nucleic Acid Encoded Oligosaccharides that Mimick the Carbohydrate Epitope of HIV. Angew. Chem. Int. Ed. 2009, 48, 7695-7700. [CrossRef]

134. Dix, A.V.; Conroy, J.L.; George Rosenker, K.M.; Sibley, D.R.; Appella, D.H. PNA-Based Multivalent Scaffolds Activate the Dopamine D2 Receptor. ACS Med. Chem. Lett. 2015, 6, 425-429. [CrossRef] [PubMed]

135. Park, E.J.; Kim, J.E.; Kim, D.K.; Park, J.H.; Lee, K.B.; Na, D.H. Glucosamine-conjugated Anionic Poly(amidoamine) Dendrimers Inhibit Interleukin-8 Production by Helicobacter pylori in Gastric Epithelial Cells. Bull. Korean Chem. Soc. 2016, 37, 596-599. [CrossRef]

136. Rosenzweig, B.A.; Ross, N.T.; Tagore, D.M.; Jayawickramarajah, J.; Saraogi, I.; Hamilton, A.D. Multivalent Protein Binding and Precipitation by Self-Assembling Molecules on a DNA Pentaplex Scaffold. J. Am. Chem. Soc. 2009, 131, 5020-5021. [CrossRef] [PubMed] 